\title{
Consequences of oil spills: a review and framework for informing planning
}

\author{
$\underline{\text { Stephanie E. Chang }}{ }^{1}$, $\underline{\text { Jeremy Stone }}^{1}, \underline{\text { Kule Demes }}^{1,2}$ and Marina Piscitelli ${ }^{1}$
}

\begin{abstract}
As oil transportation worldwide continues to increase, many communities are at risk of oil spill disasters and must anticipate and prepare for them. Factors that influence oil spill consequences are myriad and range from the biophysical to the social. We provide a summary literature review and overview framework to help communities systematically consider the factors and linkages that would influence consequences of a potential oil spill. The focus is on spills from oil tanker accidents. Drawing primarily on empirical studies of previous oil spill disasters, we focused on several main domains of interest: the oil spill itself, disaster management, the physical marine environment, marine biology, human health, economy, and policy. Key variables that influence the severity of consequences are identified, and significant interactions between variables are delineated. The framework can be used to clarify the complexity of oil spill impacts, identify lessons that may be transferable from other oil spill disasters, develop scenarios for planning, and inform risk analysis and policy debates in localities that are seeking to understand and reduce their vulnerability to potential spill disasters. As a case study, the framework is used to consider potential oil spills and consequences in Vancouver, Canada. Major increases in oil tanker traffic are anticipated in this region, creating urgent new demands for risk information, disaster management planning, and policy responses. The case study identifies particular conditions that distinguish the Vancouver context from other historic events; in particular, proximity to a densely populated urban area, the type of oil being transported, financial compensation schemes, and local economic structure. Drawing lessons from other oil spill disasters is important but should be undertaken with recognition of these key differences. Some types of impacts that have been relatively inconsequential in previous events may be very significant in a Vancouver case.
\end{abstract}

Key Words: framework; impacts; oil spills; Vancouver

\section{INTRODUCTION}

Transporting oil from production sources to consumption locations entails risks, most notably, the risk of accidental oil spills, which can cause severe damage to ecosystems and loss to human society. Globally, inter-regional trade in oil is forecasted to grow markedly in coming decades (IEA 2010). Planning for oil spill disasters requires learning from previous events, yet this is challenging because consequences are conditional upon the particular geographic, ecological, societal, and temporal contexts in which the disaster occurs. We address the need for systematic approaches to develop well-informed expectations of the potential consequences of future oil spill disasters. The scope is limited to spills from oil tanker accidents.

Although many studies and tools exist that support oil spill response planning, there remains a need for a comprehensive overview of oil spills and their consequences, particularly for regions that have not directly experienced a major spill event. For example, models can help predict trajectories of oil spills (Abascal 2009, Broström et al. 2011, Liu et al. 2013), frameworks have been developed to elucidate human dimensions of oil spill impacts (Webler and Lord 2010, Lord et al. 2012), and an entire industry exists for emergency response in oil spills. Our research complements these efforts by providing a comprehensive framework to consider the broad range of factors, biophysical as well as social, and their interactions, which influence the potential consequences of an oil spill. The comprehensive scope relates to issues beyond emergency response; for instance, to policy debates on allowing increases in oil tanker traffic and to predisaster planning for long-term recovery. This breadth is especially important in areas that have no direct experience of spill disasters and little firsthand knowledge of the complexity of their impacts. We provide a review and structured framework that can support efforts by such communities to anticipate the spectrum of issues, factors, stakeholders, and strategies that may be involved. Our research is based on two premises: first, that although previous disasters provide an essential information source for anticipating future events, not all lessons may be transferrable across locales, and " $[\mathrm{t}]$ he key to successful planning and learning from experience is that it be based on systematic assessment activities" (Lord et al. 2012:18); and second, that developing realistic expectations of oil spill consequences requires understanding the full range of impacts and interactions within and across affected systems, including marine ecosystems and socioeconomic systems.

\section{METHODS}

A comprehensive literature review was conducted, including over 300 academic, government, and industry papers and reports related to oil spills and their environmental and societal consequences, with emphasis on economic impacts (Stone et al. 2013). The literature consists largely of event case studies across disparate geographic areas and substantive domains. Several previous oil spills are prominent in the literature or otherwise especially significant. These include the 1978 Amoco Cadiz oil spill offshore of Brittany, France; the 1989 Exxon Valdez oil spill in Prince William Sound, Alaska; the 1999 Erika oil spill off the coast of Brittany; the 2002 Prestige oil spill offshore of Spain and Portugal; the 2007 MT Hebei Spirit oil spill in South Korea; the 2010 BP Deepwater Horizon oil spill, caused by an explosion on an offshore drilling platform; and British spills including the 1993 Braer and 1996 Sea Empress spills.

Based on the literature review, a framework for understanding the factors influencing oil spill impacts was developed, with an emphasis on economic impacts. Key factors or variables influencing impacts were identified in several domains: the oil spill itself, disaster management, marine physical environment, marine biology, human health and society, economy, and policy. These variables and their interactions delineate an oil spill impacts framework, which can be used to clarify the complexity of oil spill consequences, facilitate comparison across events, and support 
Fig. 1. Oil spill impacts framework. $($ BOXES $=$ outcomes, lowercasen $=$ variables, solid lines $=$ linkages between oil spill occurrence and socioeconomic impacts, dotted lines= linkages between exogenous variables and outcomes. Grey boxes indicate oil spill outcomes; green boxes, ecosystem consequences; and orange boxes, societal consequences.)

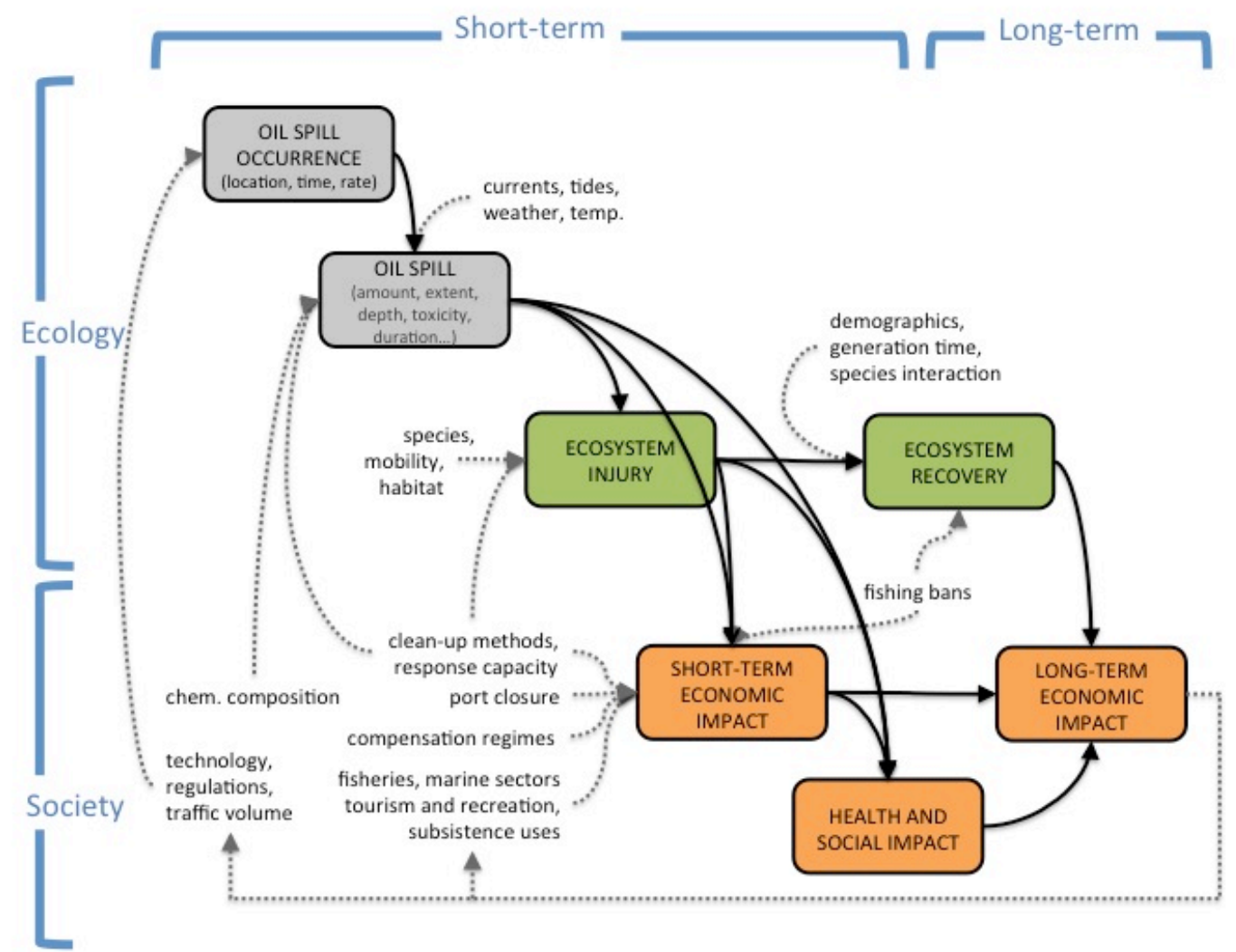

development of planning scenarios for potential future oil spills. The framework is used to consider impacts of potential oil tanker spills near Vancouver, Canada, an area facing a substantially increased risk of oil spills because of a proposed pipeline expansion project.

\section{REVIEW AND FRAMEWORK}

\section{Overview}

We present an oil spill impacts framework, which is intended to help structure the understanding of how a potential spill may affect a given locality at risk. The framework, which represents a synthesis of key findings from a broad literature, provides a mechanism for systematically and comprehensively accounting for the range of factors that influence oil spill impacts. At the core of the framework, summarized diagrammatically in Figure 1, is a linked sequence of outcomes or consequences that lead from the oil spill to its impacts on society: the occurrence of a spill event, characteristics of the particular oil spill, consequences to ecosystems in the short- and long-terms, and impacts to society in terms of economic, human health, and social consequences. A broad array of ecological and societal variables influences the severity of each of these categories of outcomes. Some of the most important variables, particularly in relation to the Vancouver case study, are identified in the figure and briefly discussed. The appendix summarizes these and other variables in tabular form to facilitate usability of the framework. Note that the intent is not to present a comprehensive and complete review of literature on oil spills; indeed, each of the sections, e.g., marine physical environment, could be the subject of an entire review paper. Rather, our objective is to synthesize key findings in an overview framework that can be used to help planners and communities recognize and systematically think through the factors and linkages that would influence consequences of a potential oil spill.

\section{Oil spill}

The first level of consequences relates to the oil spill itself (gray boxes in Fig. 1). Although each oil spill is unique, the literature suggests several key variables that influence the occurrence of oil spills and their severity, e.g., volume or physical extent. These relate to not only the oil spillage itself, but also to the disaster management response and the marine physical environment in which the spill occurs. 


\section{Oil spill event}

Several factors are important with regard to the initiating event, the oil spill itself (Appendix 1, Table A1.1). Ship safety features are a key variable, which influence the probability of occurrence. The incidence of oil tanker spills over 7 tonnes has been declining since the 1970s, a phenomenon directly correlated with the implementation of regulatory and technological changes such as mandatory improvements to ship hulls and navigation systems (Burgherr 2007, Kontovas et al. 2010, ITOPF 2012).

When a spill event occurs, one of the most important predictors of impact is its location. Spills closer to shore and human populations have greater economic impacts and are more expensive to clean. For instance, the ABT Summer spill of 1991 and the Atlantic Empress spill of 1979 were both catastrophes, with over 250,000 tonnes of oil spilled, but they had no observed effect on human populations because they occurred hundreds of miles offshore (White and Molloy 2003). Furthermore, large offshore cleanups might cost US\$300,000/tonne to clean, whereas small nearshore spills could cost US\$29,000/tonne (Kontavos et al. 2010). Another study, considering location alone, has estimated shoreline cleanup to be 4-5 times more expensive than collecting the oil at sea, and 100 times more expensive than pumping oil from the damaged vessel (Nyman 2009).

The amount of oil spilled and spillage rate are also key determinants of the severity of the consequences. A $1 \%$ increase in spill size has been estimated to raise damages by some US $\$ 0.718$ million (Alló and Loureiro 2013). Spill events that release oil slowly over time, e.g., in which the tanker is immovable and continues to release oil, may increase damages by necessitating multiple waves of response efforts. The Prestige and the Betelgeuse are examples of spills that released oil for months, accruing longterm costs associated with continual release (White and Molloy 2003, Loureiro et al. 2005, Punzón et al. 2009).

\section{Disaster management}

Disaster response and management variables directly influence the severity of an oil spill (Appendix 1, Table A1.2). A rapid response using a mix of efficient and effective technologies is critical (U.S. Department of Commerce 1983, Grigalunas et al. 1986, Moore et al. 1998, Trudel 1998, White and Baker 1998, White and Molloy 2003). A governance approach that utilizes a central on-scene command structure and incorporates prespill planning can ensure the rapid deployment of resources and effective communication of response strategies (U.S. Department of Commerce 1983, Rodin et al. 1992, Ritchie 1995, White and Molloy 2003). The capacity for local response is important. Tanker spills like the Hebei-Spirit and Amoco Cadiz have also demonstrated that volunteers and military staff can play important roles in implementing cleanup and reducing overall expense, although they present their own costs and management needs (Loureiro et al. 2005, Cheong 2011, Fourcade 2011, Tucker and O'brien 2011).

Many procedures are used to clean up oil spilled in marine environments: chemical dispersants can be applied to the oil to break down the oil into small droplets; oil can be combusted via scorching; oil can be mechanically removed; oil can be washed off the shoreline using high pressure hot water hoses; and oil can be skimmed off the surface or absorbed. All of these procedures further damage marine ecosystems and, perhaps counter- intuitively, increase the amount of time required for ecosystems to recover from the oil spill (Foster et al. 1990). The chemical dispersants used to break down oil are toxic (Judson et al. 2010, Castranova 2011, Goldsmith et al. 2011, Sriram et al. 2011), and the combination of oil and dispersant can have stronger negative effects on marine species than the oil alone (George 1961, De Vogelaere and Foster 1994, Cohen et al. 2001, Vosyliene et al. 2005). Although some algae may possess protective mechanisms against the toxic effects of dispersants (Wolfe et al. 1999), protective mechanisms in mammals are as yet poorly understood. The bioavailability of oil increases after dispersal, which can directly expose organisms to increased levels of hydrocarbons and allow the hydrocarbon-dispersant compound to enter the food chain (Mascarelli 2010). Even seemingly less destructive measures like using sorbents and skimmers can increase mortality of organisms through trampling by large cleanup crews (Foster et al. 1990).

Dispersant efficacy depends on many factors, including physical and chemical properties of the oil, composition of the dispersants, mixing energy of the system, and the ratio of dispersants to oil. Over the last few decades, dispersants have become less toxic (Judson et al. 2010). The Deepwater Horizon oil spill was unique in applying chemical dispersants not only at the surface oil slicks but also deep below the surface near the source of the leak (Kujawinski et al. 2011). This approach degrades the oil directly at the source, which minimizes intact oil at the water's surface, and assures minimal shoreline damage. Dispersants have been found to have an accelerating effect on bacteria growth and the rate of natural biodegradation in some studies (Bælum et al. 2012), but a slowing down effect in others (Hamdan and Fulmer 2011). Regardless, chemical dispersants are not very effective in degrading oil in wave-sheltered and low salinity areas because of a lack of hydrodynamic mixing (Chapman et al. 2007).

Natural processes, such as oil-eating bacteria and wave action, also help to disperse and degrade oil, and may be more effective than human efforts (Hazen et al. 2010, Gutierrez 2011). Therefore, lack of cleanup intervention is sometimes preferred to higher impact response methodologies (Foster et al 1990). From an ecological standpoint, cleanup efforts are advisable only in situations when the continued persistence of oil on the shoreline poses a greater threat than the adverse effects of the cleanup techniques on the environment (American Petroleum Institute 1985); however, decisions surrounding whether and how a cleanup will occur are strongly influenced by public and political pressures (Foster et al. 1990). Importantly, local expectations for what is 'clean' and the relative costs of cleanup in the local context can influence the intensity and expense of response activities (Wirtz et al. 2007, Nyman 2009, Kontovas et al. 2010, Fingas 2012, Alló and Loureiro 2013).

\section{Marine physical environment}

In addition to oil spill response, key variables in the marine physical environment will control which areas are exposed to oil, the quantity of oil reaching shore, and the residence time of oil in the system (Appendix 1, Table A1.3). Ambient weather conditions can restrict cleanup efforts and/or change the direction of oil dispersal. For example, high winds during the Sea Empress spill inhibited the ability of oil to be recovered at sea (Law and Kelly 2004). In contrast, shifting winds and ocean currents are 
credited with moving most of the oil spilled in the Castillo de Bellver accident offshore.

The hydrodynamic conditions at the time of a spill are arguably the most important variables influencing the dispersal and residence time of oil in the marine environment and can be broken down into wave exposure and patterns of tides and currents. Tides and currents at the time of the spill will influence the direction of the oil's dispersal whereas increased exposure to waves will increase the mechanical mixing energy available for natural oil dispersal and effectiveness of chemical dispersants (Owens et al. 1987, Carls et al. 2001). Even geographically proximate sites can differ in characteristics that influence an oil spill's impact, such as current flow rates, wave exposure, and substrate, i.e., rocky outcrop vs. sandy beaches.

\section{Ecosystem impact}

The second level of consequences relates to ecosystem injury and recovery from the oil spill (green boxes in Fig. 1). Marine ecosystems are structured in complex ways by many interacting species, and an oil spill will have a different impact on each of them. Although each ecosystem is unique, previous oil spills suggest several key variables (Appendix 1, Table A1.4). The chemical composition and quantity of the oil to which organisms are exposed are important factors determining how populations will respond to spilled oil.

Some biological traits make certain species more likely to be exposed to oil than others; particularly, the habitat/depth of the species. Under most circumstances, spilled oil will float along the surface of the water, thereby minimizing exposure of most subtidal species to oil. Notable exceptions include species with canopies that reach the surface of the water, such as some kelp and seagrass species. Marine mammal and bird species, which must regularly pass through the air-water interface to breathe, are particularly vulnerable to oil exposure (Peterson et al. 2003), whereas pelagic fish species will have minimal exposure to oil (Paine et al. 1996). In spill disasters in which the oil floats, the greatest exposure will occur in the intertidal zone, where rising and falling tides bring species in direct contact with the bulk of the spilled oil.

Toxicity pathways in different species are myriad and some examples may include ingestion of oil, accumulation of contaminants in tissues, DNA damage, impacts to immune functioning, cardiac dysfunction, mass mortality of eggs and larvae, e.g., in fish, loss of buoyancy and insulation for birds, and inhalation of vapors (Ormseth and Ben-David 2000, Rogers et al. 2002, Ma et al. 2003, Kazlauskiene et al. 2008, Incardona et al. 2009, Aguilera et al. 2010, Judson et al. 2010, Major and Wang 2012). Species will differ in their response to an oiling event because of their morphological and physiological traits, which are dictated by underlying genetic differences. Consequently, predictions for how local species will respond to an oil spill can be gleaned from information on the impact of previous spills on genetically related species. For instance, barnacle populations are generally resilient to even direct exposure to oil (George 1961, Nelson-Smith 1971, 1973), whereas amphipod species generally experience strong and long-lasting population declines in response to oiling (Hartog and Jacobs 1980, Jacobs 1980, Cross et al. 1987, Jewett and Dean 1997, Jewett et al. 1999). Nonetheless, subtle differences among even closely related species can result in divergent responses to oiling events (North 1973).
Recovery rates vary drastically depending upon characteristics of the spill, cleanup, habitat, and species. The residence time of oil in a marine environment is a function of spill release, local hydrodynamic regime, and degradation/removal processes. Once oil has reached the shoreline, residence time of the oil, and therefore its impact on marine life, will depend on the substrate, i.e., rocky vs. sandy, and local hydrodynamic conditions at the site. Five years after the Exxon Valdez oil spill, $2 \%$ of the original oil remained on beaches and $13 \%$ in sediments. At some low wave energy sites in Alaska, oil was calculated to take 30 years to return to background levels (Carls et al. 2001).

Variation in recovery rates among species likely varies broadly as a function of generation time. Research on recovery of marine species in France after the Amoco Cadiz spill indicated that populations may take 3-6 generations to recover (Conan et al. 1982). This suggests that for short-lived species, recovery may be achieved in only a few years, whereas populations of perennial species take much longer to recover, resulting in communities dominated by short-lived species. Bivalves may recover in as quickly as 5-10 years, whereas longer-lived bird and mammal species may take decades to recover from an oil spill (Matkin et al. 2008).

Ecosystem response to an oil spill is dependent upon both direct impacts on species and indirect impacts through altered species interactions. An increase in urchin abundance was observed after the Exxon Valdez oil spill because of oil-related mass mortality of its dominant predator, the sea otter (Dean et al. 2000). Similarly, increases in abundance of sea lettuce (Ulva spp.) have been observed after an oil spill as a result of release of competitive pressure by other seaweed species (Bellamy et al. 1967). On the other hand, reduction of positive interactions, i.e., facilitation, can also result in delayed recovery (van Tamelen et al. 1997).

\section{Societal impact}

A third level in the framework pertains to consequences of the oil spill on human society (orange boxes in Fig. 1), including interrelated impacts on health of individuals, well-being of communities, and the economy. Webler and Lord (2010) provided taxonomies of processes, impacts, and vulnerabilities associated with human dimensions of oil spills. Broadly speaking, they noted that humans can be affected by oil spills in three major ways: oil can affect ecological processes that cause direct harm, e.g., health impacts from eating seafood with bioaccumulated oil toxins; oil spill stressors can change intermediary processes, e.g., economic impacts to fishers from oil spill impacts to fish; and stressors can directly harm humans, e.g., health impacts from breathing oil vapors. In the current framework, these processes are reflected in Figure 1 in the different paths by which an oil spill leads to economic, health, and social impacts. The review and framework here emphasize key variables from the empirical literature and how they influence the severity of socioeconomic impacts.

\section{Human health and society}

The literature indicates a number of key variables and processes that influence health and social impacts (Appendix 1, Table A1.5). In terms of physical health, direct contact with crude oil, or indirect contact through, for example, inhalation of vapors or consumption of tainted seafood can cause deleterious health effects ranging from dizziness and nausea to certain types of cancers and issues with the central nervous system (Jenssen 1996, Davidson et al. 2005, Herrington et al. 2006, Rodríguez-Trigo et 
al. 2007, Jacques Whitford 2008, Aguilera et al. 2010, Major and Wang 2012). Although long-term hydrocarbon toxicity effects on humans are less understood (Binet et al. 2002, Aguilera et al. 2010), they have been linked, in addition with volatile organic compounds (VOCs), with causing severe DNA degradation, cancers, birth and reproductive defects, irreversible neurological and endocrine damage, and impaired cellular immunity (Rodríguez-Trigo et al. 2007, Zock et al. 2007, Aguilera et al. 2010, Major and Wang 2012). Volatile organic compounds are often used as diluents in oil transport and processing and are considered to be the main pollutants in crude oil with varied health effects depending on the type and amount of chemical(s) used in the operation (Goel 2011).

Moreover, a review of 130 disasters found that technological disasters in the United States, like oil spills, were more psychologically stressful than natural disasters (Picou et al. 2004). Threatened livelihoods coupled with new flows of recovery money into the community have been associated with various forms of stress and social breakdown. Following Valdez, high rates of alcohol and drug use were associated with recovery jobs, especially in Indigenous communities, and there were higher rates of domestic violence and crime more broadly (Rodin et al. 1992, Palinkas et al. 1993). This, in turn, led to increased demands on clinic, mental health, and rehabilitation programs (Rodin et al. 1992, Palinkas et al. 1993). These impacts not only have direct costs through hospital bills and related expenses, but they also have a broader social cost through, for example, work stoppages and shorter life expectancy (Loureiro et al. 2005, Moore et al. 1998).

The social fabric of communities can also be threatened by the influx of outsiders, the unequal distribution of cleanup jobs, and shifts in family/community hierarchies, e.g., when sons became cleanup managers over their fathers, etc. (Palinkas et al. 1993). Oil spills also affect aboriginal communities and ethnic or rural enclaves that rely on the natural environment for subsistence and social-cultural uses (Rodin et al. 1992, Palinkas et al. 1993, Martin 1999, Fall et al. 2001, Esclamado 2011, Rhoan 2011). There are provisions for subsistence losses in most compensatory frameworks, but the full spectrum of socio-cultural losses may have an impact on social structure and community stability, and further erode productivity and economic participation.

Social impacts have, however, been alleviated in some spill events, e.g., Hebei-Spirit and Prestige, by interim aid payments, NGO support, volunteer mobilization, support from unaffected populations, and other efforts to provide necessary assistance to affected populations (Loureiro et al. 2005, Surís-Regueiro et al. 2007, Cheong 2011). One study of the Galician coast affected by the Prestige spill found that, in contrast to the Valdez case, there was no significant impact on mental health, social relationships, or confidence in institutions, because of the strong support of social groups and appropriate levels of interim financial aid (Sabucedo et al. 2009).

\section{Economy and policy}

The economic impact of an oil tanker spill is difficult to evaluate with precision, given the limitations in available baseline data, long-term forecasting methods, and estimation of nonmarket costs. Although direct property damage is fairly easy to ascertain, causality between oil spills and broader losses in income and market share is difficult to establish. Furthermore, the process of valuation itself is in many ways a socio-cultural construct that varies across contexts. The literature indicates several key variables related to the local economy (Appendix 1, Table A1.6) and decision-making and policy interventions (Appendix 1, Table A1.7).

Historic oil spills indicate that some industries regularly experience losses caused by direct damage or market impairment. Commercial fisheries and aquaculture businesses are usually affected by loss of product, caused by direct mortality or habitat loss, or by loss of access caused by harvesting bans and closures (Moldan et al. 1985, Grigalunas et al. 1986, Goodlad 1996, Martin 1999, Moller et al. 1999, Punzón et al. 2009). Losses are also incurred because of a decline in market demand amid fears of tainted products (Moncrieff and Simpson 1993, Pearson et al. 1998, Garza-Gil et al. 2006, Surís-Regueiro et al. 2007, Cheong 2012). These losses then ripple throughout the fisheries supply chain, affecting docks, processors, and supply businesses (U.S. Department of Commerce 1983, Moncrieff and Simpson 1993, García Negro et al. 2009).

Similarly, the tourism industry can be harmed by direct impact to beaches and waterfront properties, as well as by the brand damage incurred by diminished public perception and negative media coverage (U.S. Department of Commerce 1983, Oxford Economics 2010). Losses may be experienced in tourism subsectors such as accommodations, transportation, guides, activities, and recreational fisheries (McDowell Group 1990, Moore et al. 1998). In surveys after Exxon Valdez, 59\% of tourism businesses in the spill area reported spill-related cancellations, and visitor spending decreased 35\% from prespill levels in Southwest Alaska (McDowell Group 1990). Retail and restaurant establishments that cater to the tourism industry are also exposed to losses in sales and wages (U.S. Department of Commerce 1983, Martin 1999, Loureiro et al. 2005). Moreover, regional businesses not directly affected by the spill may suffer losses from brand damage.

Other marine-based industries such as port businesses, sea-based transportation, and industries that use sea water as production inputs are also at risk from oil spills, although the monetary impact is usually not as severe (U.S. Department of Commerce 1983, Moore et al. 1998, Wirtz et al. 2007). The broader economy may experience pure economic losses caused by reduced disposable income or market demand (Jacobsson 2007). However, pure economic losses are especially difficult to measure or establish causality and, as such, are rarely compensated by international compensatory regimes like the Civil Liability Convention of 1992 (Palmer 2011, Perry 2011).

Compensation regimes for financing response and recovery play a crucial role in ameliorating economic impacts of oil spills. A network of two conventions and three funds provides the regulatory and compensatory framework for most international tanker spills: the 1969 and 1992 International Conventions on Civil Liability for Oil Pollution Damage (CLC), the 1971 and 1992 conventions on the establishment of an International Fund for Compensation for Oil Pollution Damage (IOPC), and the 2005 Convention for the International Oil Pollution Compensation Supplementary Fund (Kiran 2010, Schoenbaum 2012). The CLC and its related funds limit the liability of oil tanker owners and 
provide up to US\$1.18 billion in compensation for cleanup and economic loss (Boulton 2010, Kiran 2010, Billah 2011). Some 130 countries, including Canada, are parties to these conventions, but the United States has established its own funds and protocols through the Oil Pollution Act (OPA; Mason 2002, Schoenbaum 2012). Unlike CLC 1992, OPA imposes strict liability on all "responsible parties" including the owners, operators, and charterers of the ship. Moreover, there is a greater ability for claimants to pursue unlimited damages under OPA than from the CLC 1992 (Schoenbaum 2012).

Some countries have additional funds available; for example, Canada operates a Ship-source Oil Pollution Fund that provides an additional Can\$161 million as a fund of last resort (SOPF Administrator 2013). This amount of funding would have covered the admissible claims of almost all historic spills on record (Jacobsson 2007, Billah 2011). However, not all claims are admissible, and international regimes do not require affected environments to be fully remediated to prespill levels (Mason 2002, 2003, Garza-Gil et al. 2006, Liu and Wirtz 2006, Jacobsson 2007, Schoenbaum 2012). Moreover, compensation processes suffer from issues of application capacity, inequitable distribution of benefits, and a procedural timeframe that is shorter than the time required to measure long-term effects (Rodin et al. 1992, Palinkas et al. 1993, Hill and Bryan 1997, Moore et al. 1998, Mason 2003, Loureiro et al. 2005, Cheong 2011).

Loss in passive use and recreation value of the environment can represent a sizable economic impact (McCammon 2003, García Negro et al. 2007, Fourcade 2011). Estimates following spills such as the Prestige and Valdez have easily reached the billions of dollars, comprising the bulk of the economic loss valuations (Carson et al. 2003, Garza et al. 2009, Loureiro et al. 2009). Such estimates are made using contingent valuation techniques, which are subject to criticism and also not accepted by international compensatory regimes, although they are accepted under the Oil Pollution Act in the United States (Assaf et al. 1986, Carson et al. 2003, Garza-Gil et al. 2006, Fourcade 2011, Schoenbaum 2012).

Once the recovery is under way, other factors can ameliorate the overall economic and financial impact for communities. Shortterm increases in spending for disaster response personnel can create a 'recovery boom,' which benefits tourism businesses, such as accommodations and transportation, and local retailers, contractors, and workers, who are displaced from primary industries (Rodin et al. 1992, U.S. Department of Commerce 1983, Butler and Fennell 1994, Hill and Bryan 1997, Cheong 2011). In this sense, a focus on local procurement after disasters can soften impacts on the local economy and increase short-term tax revenues for affected municipalities (U.S. Department of Commerce 1983, Barker 2011). Economic loss can also be reduced by business savings on operating costs and conservation benefits for target species of fisheries and other resource extraction industries (U.S. Department of Commerce 1983, Moller et al. 1999, Hill and Bryan 1997, Loureiro et al. 2005, Garza-Gil et al. 2006, Punzón et al. 2009).

\section{VANCOUVER CASE}

Although the framework and the literature reviewed on historic oil spill impacts provide a basis for anticipating impacts of future spills, it is important for communities at risk to recognize the particularities of their situation and how these might be similar to or different from those of previous cases. An illustration for the case of Vancouver, Canada, demonstrates the importance of identifying distinctive aspects of the local case and understanding their implications from a systems perspective.

Vancouver is an example of a coastal metropolitan area facing the possibility of substantially increased oil tanker traffic and the associated risk of oil spills. Canadian oil sands account for half of the world's increase in proven oil reserves since 2000 (IEA 2010). As oil exporters seek modes of transporting fossil fuels from the oil sands in northern Alberta to international markets, one pipeline company is proposing a project that would approximately treble the existing capacity of an oil pipeline from Alberta to marine terminals in the Metro Vancouver area; oil tanker traffic is expected to increase five-fold (CRED 2013). The terminals and marine access through Burrard Inlet would be immediately offshore of the urban area (see Fig. 2).

Fig. 2. Vancouver Area Map.

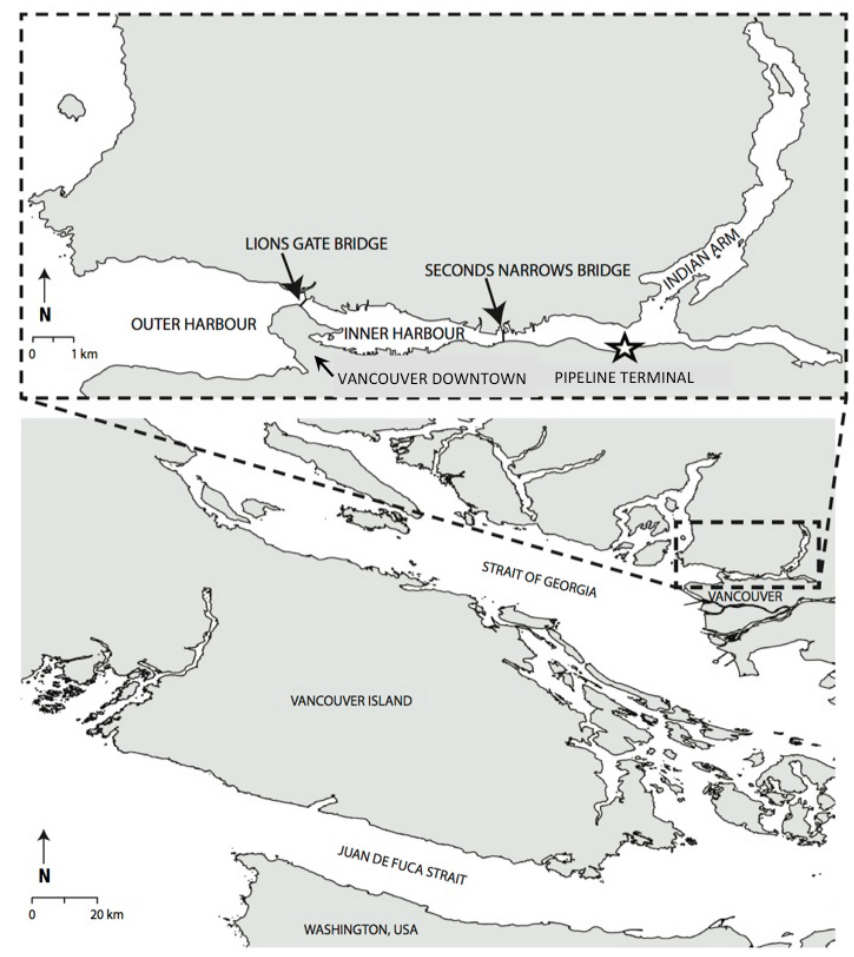

The proposed project raises many complex issues, concerns, and debates, and there is a need for more information and better planning. To date, no major oil spills have occurred in the waters near Vancouver; hence there is little direct knowledge of oil spill consequences in the community, e.g., among elected officials, planners, and the public. Emergency response plans and capacity remain largely untested, outside of exercises. A basic question remains: if an oil spill from a tanker accident were to occur in or near Burrard Inlet, how would it affect the environment, population, and economy? No comprehensive scenarios of potential oil spills have yet been developed or at least been made publicly available, nor is information publicly available on the likelihood of spills and their expected volumes, types, and 
associated uncertainties. Spill scenarios used by the authorized oil spill response organization are based on spill volume rather than impacts, e.g., a tabletop exercise is conducted once every three years for a 10,000 tonne spill. Moreover, they are designed for contingency planning, in accordance with the response organization's mandate and requirements for certification (WCRMC 2012).

In this context, the literature reviewed and the oil spill impact framework were applied in support of efforts to learn from oil spill disasters that have occurred elsewhere while systematically considering the local context. Several key insights from this preliminary analysis demonstrate the importance of a systematic and comprehensive approach.

First, the proximity to a densely populated urban area with over 2 million residents has many ramifications. No major oil tanker spills have occurred, to date, in similarly urban coastal settings. To reach the terminal facilities, oil tankers must pass by downtown Vancouver through Burrard Inlet, a busy port and harbor area (Fig. 2). In comparison with remote locations, the likelihood of tanker accidents may be higher as a result of the traffic; however, this is at least partly ameliorated by stricter safety regulations and standards. For example, when entering local waters, all tankers must take aboard two trained local pilots who physically steer the ships through the waterways (Port Metro Vancouver 2012). By virtue of proximity, a large human population would be exposed to the oil spill impacts. The near-shore location of the oil spill would also entail substantially higher cleanup costs than an offshore event. It is reasonable to expect that because of its proximity to a large population, the visibility of a spill would entail intensive cleanup efforts and stringent expectations for what would be considered acceptably 'clean.'

Second, local conditions in the marine physical environment, in particular, wave exposure, tides and currents, and connecting waterways, would lead to dispersion patterns that may be quite distinct from offshore events. Many of the processes that influence the fate of oil after a spill, e.g., evaporation, emulsification, and sedimentation, are difficult to predict without knowing specific characteristics of the oil and ambient weather conditions, but some general trends can be described from general local hydrodynamic conditions. Vancouver, located on the mainland, is protected from oceanic waves by Vancouver Island, and the inner and central harbors of Burrard Inlet are both protected from wind waves as well; consequently, natural dispersion via mechanical mixing of oil is expected to be low in this area. The local hydrodynamic regime will also have an impact on the effectiveness of cleanup measures. For instance, chemical dispersants are not very effective in degrading oil in such wavesheltered areas because of a lack of hydrodynamic mixing, but vessel-based cleanup methods, such as skimming, may be more successful in calm waters. Although exposure to waves will vary seasonally, e.g., winter storms, in general, wave-sheltered sites will see less intra-annual variation in wave energy than will sites exposed to oceanic waves.

Tide and current patterns, on the other hand, display tremendous variability on the scale of hours because of incoming vs. receding tides, weeks because of lunar cycle, and months because of seasons. The Strait of Georgia, the body of water in which Vancouver is located, exhibits high tidal ranges, and many narrow passageways throughout the area experience extreme tidal currents (Thomson 1981). Models of oil spills in the Burrard Inlet show drastically different oil spill dispersion patterns based on variation in currents. For instance, a spill occurring just outside the Burrard Inlet in one season may rapidly leave the inlet and hit shore in other municipalities, whereas a spill at that same location in another season may travel in the opposite direction, further up the inlet (Thomson 1981, David Suzuki Foundation 2013).

Organisms living in the intertidal zones bordering the inlet are especially likely to be exposed to spilled oil. The large tidal range in this region, coupled with the shallow sloping coastline, cause this habitat to be larger than in many areas of the world, potentially exposing a relatively large area to spilled oil. In addition to injury to the intertidal ecosystems of Burrard Inlet, shallow subtidal bull kelp (Nereocystis luetkeana) and eelgrass (Zostera marina) systems are also likely to incur immediate damage through loss of canopy.

Because tides and current patterns can move spilled oil considerable distances, connecting waterways represent another important factor. An oil spill in the waters near Vancouver may threaten coastlines of several jurisdictions, including Canadian municipalities and potentially neighboring U.S. localities, indicating the importance of communication and cooperation among neighboring municipalities concerning risks of oil spills.

A third distinctive aspect pertains to the type of oil that would be transported in the proposed pipeline expansion project, diluted bitumen. Bitumen is a product of tar sands and the heaviest form of crude oil produced (Stubblefield et al. 1989, Masliyah et al. 2004, Upreti et al. 2007). Because of its high density, bitumen is first diluted to facilitate transportation through pipelines. Although the exact chemical composition of the diluted bitumen being shipped through the port of Vancouver is a trade secret, diluents are commonly volatile organic compounds (VOCs), which are toxic to wildlife and humans (Stubblefield et al. 1989, Upreti et al. 2007).

There have been no previous tanker spills of bitumen. A 2010 pipeline rupture near Kalamazoo, Michigan, which contaminated nearby waterways, is the only spill to date of dilute bitumen (CRED 2013). In that event, VOCs evaporated and became airborne within hours, causing hundreds of residents within a mile of the spill to be evacuated for acute health symptoms (NTSB 2010). Vaporized toxins pose a threat to human health (Binet et al. 2002, Gosselin et al. 2010, Kelly et al. 2010, Goel 2011, McLinden et al. 2012). This, combined with dense human population, suggests that a bitumen spill in Burrard Inlet can potentially have unprecedented impact on human health.

With regard to marine species, there is limited information on responses of many of the local, ecologically important species; furthermore, no published data exist on toxicity of bitumen to marine species in this area. One notable example is the potential for an oil spill to increase the invasion success of the recently introduced nonindigenous species, Littorina littorea or common periwinkle (Harley et al. 2013). This species is thought to be more resilient to oil spills (North 1973) and would likely benefit if populations of its competing native relatives suffered declines from an oil spill event. Although no studies were found in this review that directly linked oil spills to success of invasive vs. native 
species, the idea that invasive species may benefit preferentially over native species in polluted waters is not novel (Piola and Johnson 2008, McKenzie et al. 2012).

Importantly, there is some uncertainty regarding how bitumen would interact physically with the marine environment. If the bitumen sinks, as was the case in the Kalamazoo spill, in addition to intertidal and shallow subtidal systems, subtidal ecosystems and pelagic fish will also be at risk of oil exposure. If bitumen sinks, this would also have implications for the effectiveness of different types of cleanup technologies.

In the societal domain, a fourth important aspect pertains to local capacity and governance structure for responding to an oil spill, which in Vancouver are largely untested. In principle, there is a public-private structure whereby tanker owners and an authorized oil spill response organization, the Western Canada Marine Response Corporation (WCMRC), are responsible for the immediate response, and federal and provincial authorities provide oversight and long-term management of the response in cases of noncompliance (Office of the Auditor General of Canada 2010, DFO 2011, BC-MOE 2013, Port Metro Vancouver 2013). However, a lack of harmonization between federal and provincial oil spill response policies may result in coordination issues in the event of an emergency (Office of the Auditor General of Canada 2010).

Moreover, the current federal and provincial oil spill response plans only focus on immediate cleanup and cost recovery and do not address economic impacts or longer term recovery planning (Transport Canada, 2010, DFO 2011; BC-MOE 2013). No response and recovery planning is conducted at the municipal level in Vancouver. The literature review suggests that the majority of the impacts on human systems occur outside of the response phase of an oil spill cleanup, so the lack of a recovery plan creates significant exposure for the region in the event of an oil spill.

The capacity of the local response has also been questioned, particularly in the context of projected increases in tanker traffic. Federal law only requires spill response organizations to maintain resources for a 10,000 tonne spill, which is far below the amount necessary for spills like the Prestige and Valdez (Office of the Auditor General of Canada 2010, BCG 2012). Scenario planning and oil spill response exercises are only developed up to the 10,000 tonne level (WCMRC 2012, MOJ 2013). For liability reasons, volunteers are not permitted to be involved in local cleanup activities, and foreign oil-spill responders are not indemnified from results of their work in Canada, thus rendering mutual aid agreements ineffective (EnviroEmerg Consulting 2008, Office of the Auditor General of Canada 2010, Pacific States/British Columbia Oil Spill Task Force 2011, BCG 2012, Vanderklippe 2012, BC-MOE 2013). Recently, the federal government of Canada has announced new initiatives in tanker safety (Bailey 2013).

A fifth noteworthy aspect pertains to the financial compensation schemes that would apply to an oil spill in Canadian waters. As noted above, Canada is a party to the international CLC/IOPC network of conventions and funds that apply to most international tanker spills, whereas the U.S. has established its own funds and protocols through the Oil Pollution Act (OPA; Mason 2003, Schoenbaum 2012). Canada also operates a supplementary Ship-source Oil Pollution Fund as a fund of last resort (Administrator of the Ship-source Oil Pollution Fund 2013). Financial compensation in a Canadian oil spill disaster would thus differ from experiences in U.S. events. For example, under CLC/IOPC, the ship owner is strictly liable for the oil spill, whereas under the OPA, the federal government can seek damages from a range of parties beyond the tanker owner (Schoenbaum 2012). Also, under the international conventions, environmental damages are rarely compensated beyond cleanup and lost profits in fisheries and other marine sectors; in contrast, the OPA explicitly provides for the recovery of damages to natural resources (Schoenbaum 2012).

A final point of distinction for a Vancouver oil spill, and one that relates to many of the others already noted, pertains to the structure of the local economy. In contrast to major historic oil spills, which primarily affected small, resource-dependent communities, the urban setting here comprises not only a large population with high density, but also an economic structure that is linked in very different ways to the coastal environment. For example, commercial fisheries and aquaculture play a very limited role in Vancouver's economy, although the urban area does serve as a landing and processing hub for regional fisheries (Levings and Samis 2001, MMK Consulting 2007, Port Metro Vancouver 2012). There are also numerous First Nations, i.e., aboriginal groups, in the area that utilize the natural environment for economic, subsistence, and socio-cultural uses. Marine pollution that taints harvested species and adversely affects the health of First Nation communities is a growing concern in the region (Mos et al. 2004). Estimates of oil spill impacts to First Nations in another region, the north coast of British Columbia, have ranged into the billions of dollars (Gunton and Broadbent 2012). Because of traditional land rights and their reliance on the marine environment, First Nation are becoming increasingly involved with marine resource planning in British Columbia (Jones et al. 2010) and may also need to be included in oil spill response decision making.

Economic sectors that are important in Vancouver, but which were not prominent in other oil spill disasters, may also be vulnerable to oil spills. The Port employs 44,000 people and generates Can\$3.5 billion in GDP for Metro Vancouver (Intervistas 2009). Although the impact of port closures has been relatively minor in other contexts, the potential for closure of the Vancouver port could have a more dramatic effect. Tourism is a major sector and accounts for 80,000 jobs in the local economy (BC-MJTI 2012). Real estate plays a complex but significant role in Vancouver's economy and has become a key element of economic growth (Barnes et al. 2011). Vancouver is regularly ranked as one of the world's most livable cities. Like tourism, real estate activity, which is driven by out-of-town investors, may be vulnerable to the intangible impact of an oil spill on Vancouver's image and reputation.

Ironically, for an urban area such as Vancouver, an oil spill at some distance from the urbanized coastline may be as economically damaging as one occurring nearby: reputational damage may be incurred regardless of actual geographic proximity to the spill, causing attendant losses to major economic sectors such as tourism. With little direct damage that would be considered admissible as claims under compensation regimes, the 
inflow of compensation funds to help offset losses may be very limited.

This preliminary analysis can support further activities by the city and region to understand, manage, and reduce the risk of marine oil spills, activities such as identifying likely spill scenarios, developing comprehensive, and where possible, quantitative, portrayals of their impacts, and using such scenarios to engage a broad spectrum of stakeholders to raise awareness and increase resilience. Development of a socioeconomic recovery plan would be important for clarifying impact and compensation and for addressing gaps in standard recovery mechanisms.

The preliminary analysis also identifies several key knowledge gaps. Research is needed on the differences in behavior of crude oil and diluted bitumen when spilled and on the toxic effects of their components on local marine species. Dynamic modeling of a spill in key areas of Burrard Inlet is important for providing information on dispersal rates and pathways and to illuminate particularly vulnerable habitats/areas. Investigations of other technological and natural disasters in coastal cities are needed to augment the knowledge base; for example, examining imagerelated impacts on tourism and other sectors. Such studies could be complemented by local interviews to identify causal chains of human dimension impacts (Webler and Lord 2010). An audit of actual spill response capacity on the West Coast of Canada is needed to identify potential gaps and inform preparedness planning.

Gaps also exist in baseline studies that would be required for further planning efforts. Comprehensive baseline assessments of natural resources and socioeconomic entities in the region are important for informing environmental and economic impact studies and recovery plans and would also facilitate accurate monitoring after a spill has occurred. In the Vancouver case, an interagency partnership, the Burrard Inlet Environmental Action Program, now disbanded, has compiled baseline data on habitat types, intertidal vegetation, number of bird nests, outfalls, docks, impervious surfaces, and numerous other coastal conditions in the inlet. Although such baseline data can be used to rank environmentally sensitive areas to inform a hierarchy of response efforts in the event of an oil spill, data have not addressed population levels of species within Burrard Inlet, which is helpful for determining species most at risk and essential for quantifying impacts of a spill event. Moreover, baseline data on human populations and economic activities at risk have not been assembled for purposes of oil spill risk analysis and are also crucial.

\section{CONCLUSION}

The risk of marine oil spills raises many planning and policy issues, from permitting or prohibiting increased oil transport volumes, to developing the capacity to respond to and recover from potential spill disasters. Underlying these issues is the need for informed expectations about the potential consequences of oil spills. The empirical evidence base is not large: only a few spills have been extensively documented, and most studies focus narrowly on specific aspects. It is thus important to draw on the entire knowledge base and to recognize that some historic disasters may be more informative than others in making predictions for a different context.
We have provided a synthesis review of disparate literatures related to marine oil spills and have summarized key factors in an oil spill impact framework. The breadth of this review and framework can assist communities at risk, particularly those without prior experience with oil spills, to develop an overview of the spectrum of potential impacts and the key biophysical and socioeconomic factors that influence how these impacts are realized. Such an overview represents an initial and important input into the larger process of addressing the risk of oil spill disasters.

A comprehensive overview can help clarify the complexity of oil spill disasters, make comparisons across events, identify data gaps, and develop planning scenarios in preparation for future oil spill disasters. It can facilitate understanding of how a spill of a particular volume could lead to very different consequences, depending upon contextual variables and their interactions. The impact of an oil spill on commercial fisheries and aquaculture would depend, for instance, upon factors including the oil spill's volume and location relative to fishing/cultivation areas; currents, tides, and wave action that disperse the oil; the types of species harvested in the region, e.g., whether species are sedentary or mobile; and government decisions relating to fishing bans and compensation schemes. In the Vancouver case study, preliminary analysis identified several complexities that are critical to recognize in planning efforts, such as the high variability in potential spill outcomes related to marine physical conditions, behavior of diluted bitumen, and uncertainties regarding local response capacity, as well as the limitations of financial compensation schemes, and the multilayered implications of proximity to an urban population and economy.

In the longer term, one priority for further research would be to incorporate the key variables and interactions into integrated models, which can provide scenarios of potential oil spill impacts in particular localities. Such models would consider not only oil dispersion but also ecological impacts and linkages to human health and economic impacts. In view of substantial uncertainty, a sensitivity analysis would be essential. Such models could address questions such as what would be the worst-case disaster, what pre- and postdisaster interventions are critical, and what interventions are robust in reducing losses over a broad range of possible spill events. These insights are important for policy and planning aimed at reducing the likelihood of oil spills, providing effective emergency response, and facilitating recovery.

\section{Responses to this article can be read online at: http://www.ecologyandsociety.org/issues/responses. php/6406}

\section{Acknowledgments:}

This study was supported in part by the Vancouver Economic Commission (VEC) and by the Marine Environmental Observation, Prediction, and Response (MEOPAR) Network of Centres of Excellence (NCE). Any opinions, findings, conclusions, or recommendations expressed are the authors' and do not necessarily reflect those of VEC or MEOPAR. We thank the editor and anonymous referees for their advice on this paper. 


\section{LITERATURE CITED}

Abascal, A. J., S. Castanedo, R. Medina, I. J. Losada, and E. Alvarez-Fanjul. 2009. Application of HF radar currents to oil spill modelling. Marine Pollution Bulletin 58:238-248.

Administrator of the Ship-source Oil Pollution Fund. 2013. Shipsource oil pollution fund: the administrator's annual report 2012-2013. Administrator of the Ship-source Oil Pollution Fund, Ottawa, Ontario, Canada. [online] URL: http://ssopfund.gc.ca/ CMFiles/reports-en/AnnualReport2012-2013-en.pdf

Aguilera, F., J. Méndez, E. Pásaro, and B. Laffon. 2010. Review on the effects of exposure to spilled oils on human health. Journal of Applied Toxicology 30(4):291-301. http://dx.doi.org/10.1002/ jat. 1521

Alló, M., and M. L. Loureiro. 2013. Estimating a meta-damage regression model for large accidental oil spills. Ecological Economics 86:167-175. http://dx.doi.org/10.1016/j.ecolecon.2012.11.007

American Petroleum Institute. 1985. Oil spill response: options for minimizing adverse ecological impacts. American Petroleum Institute, Washington, D.C., USA.

Assaf, G. B., B. G. Kroetch, and S. C. Mathur. 1986. Nonmarket valuations of accidental oil spills: a survey of economic and legal principles. Marine Resource Economics 2(3):211-237.

Baars, B.-J. 2002. The wreckage of the oil tanker 'Erika'-human health risk assessment of beach cleaning, sunbathing and swimming. Toxicology Letters 128:55-68. http://dx.doi. org/10.1016/S0378-4274(01)00533-1

Bælum, J., S. Borglin, R. Chakraborty, J. L. Fortney, R. Lamendella, O. U. Mason, M. Auer, M. Zemla, M. Bill, M. E. Conrad, S. A. Malfatti, S. G. Tringe, H.-Y. Holman, T. C. Hazen, and J. K. Jansson. 2012. Deep-sea bacteria enriched by oil and dispersant from the Deepwater Horizon spill. Environmental Microbiology 9:2405-2416. http://dx.doi.org/10.1111/ j.1462-2920.2012.02780.x

Bailey, I. 2013. Ottawa tightens tanker safety with \$120-million plan. Globe and Mail, March 18. [online] URL: http://www. theglobeandmail.com/news/british-columbia/ottawa-tightens-tankersafety-with-120-million-plan/article9905060/

Barker, K. 2011. 'Spillionaires' are the new rich after BP oil spill payouts. Washington Post, April 13.

Barnes, T., T. Hutton, D. Ley, and M. Moos. 2011. Vancouver: restructuring narratives in the transnational metropolis. Pages 298-321 in T. Hutton, L. Bourne, R. Shearmur, and J. Simmons, editors. Canadian urban regions: trajectories of growth and change. Oxford University Press, Oxford, UK.

Barron, M. G. 2012. Ecological impacts of the deepwater horizon oil spill: implications for immunotoxicity. Toxicologic Pathology 40(2):315-320. http://dx.doi.org/10.1177/0192623311428474

Bellamy, D. J., P. H. Clarke, D. M. John, D. Jones, A. Whittick, and T. Darke. 1967. Effects of pollution from the Torrey Canyon on littoral and sublittoral ecosystems. Nature 216:1170-1173. http://dx.doi.org/10.1038/2161170a0

Billah, M. M. 2011. The role of insurance in providing adequate compensation and in reducing pollution incidents: the case of the international oil pollution liability regime. Pace Environmental Law Review 29(1):2.

Binet S., A. Pfohl-Leszkowicz, H. Brandt, M. Lafontaine, and M. Castegnaro. 2002. Bitumen fumes: review of work on the potential risk to workers and the present knowledge on its origin. Science of the Total Environment 300:37-49. http://dx.doi.org/10.1016/ $\underline{\text { S0048-9697(02)00279-6 }}$

Blondina, G. J., M. M. Singer, I. Lee, M. T. Ouano, M. Hodgins, R. S. Tjeerdema, and M. L Sowby. 1999. Influence of salinity on petroleum accommodation by dispersants. Spill Science and Technology Bulletin 5:127-134. http://dx.doi.org/10.1016/S1353-2561 (98)00048-6

Boulton, M. 2010. Financial vulnerability assessment: who would pay for oil tanker spills associated with the Northern Gateway pipeline? University of Victoria, Environmental Law Centre, Victoria, British Columbia, Canada. [online] URL: http://www. elc.uvic.ca/press/documents/2010-02-06-Tanker-Spill-FinancialVulnerability-Assessment Jan15\%2011.pdf

British Columbia Government (BCG). 2012. Requirements for British Columbia to consider support for heavy oil pipelines. Provincial document. British Columbia Government, Victoria, British Columbia, Canada. [online] URL: http://www.env.gov.bc. ca/main/docs/2012/TechnicalAnalysis-HeavyOilPipeline 120723. pdf

British Columbia Ministry of Environment (BC-MOE). 2013. British Columbia marine oil spill response plan. Provincial document. British Columbia Ministry of Environment, Victoria, British Columbia, Canada.

British Columbia Ministry of Jobs, Tourism, and Innovation (BCMJTI). 2012. The value of tourism in British Columbia: trends from 2000 to 2010. Provincial document. British Columbia Ministry of Jobs, Tourism, and Innovation, Victoria, British Columbia, Canada.

Brody, T. M., P. Di Bianca, and J. Krysa. 2012. Analysis of inland crude oil spill threats, vulnerabilities, and emergency response in the midwest United States. Risk analysis 32(10):1741-1749. http:// dx.doi.org/10.1111/j.1539-6924.2012.01813.x

Broström, G., A. Carrasco, L. R. Hole, S. Dick, F. Janssen, J. Mattsson, and S. Berger. 2011. Usefulness of high resolution coastal models for operational oil spill forecast: the Full City accident. Ocean Science Discussions 8(3):1467-1504. http://dx. doi.org/10.5194/osd-8-1467-2011

Butler, R. W., and D. A. Fennell. 1994. The effects of North Sea oil development on the development of tourism: the case of the Shetland Isles. Tourism Management 15(5):347-357. http://dx.doi. org/10.1016/0261-5177(94)90089-2

Burgherr, P. 2007. In-depth analysis of accidental oil spills from tankers in the context of global spill trends from all sources. Journal of Hazardous Materials 140(1-2):245-256. http://dx.doi. org/10.1016/j.jhazmat.2006.07.030

Carls, M. G., M. M. Babcock, P. M. Harris, G. V. Irvine, J. A. Cusick, and S. D. Rice. 2001. Persistence of oiling in mussel beds after the Exxon Valdez oil spill. Marine Environmental Research 51(2):167-190. http://dx.doi.org/10.1016/S0141-1136(00)00103-3 
Carson, R. T., R. C. Mitchell, M. Hanemann, R. J. Kopp, S. Presser, and P. A. Ruud. 2003. Contingent valuation and lost passive use: damages from the Exxon Valdez oil spill. Environmental and Resource Economics 25:257-286. [online] URL: http://gspp.berkeley.edu/assets/uploads/research/pdf/ Exxon_Valdez_Oil_Spill.pdf

Castranova, V. 2011. Bioactivity of oil dispersant used in the Deepwater Horizon cleanup operation. Journal of Toxicology and Environmental Health, Part A: Current Issues 74(21):1367. http:// dx.doi.org/10.1080/15287394.2011.606792

Conversations for Responsible Economic Development (CRED). 2013. Assessing the risks of Kinder Morgan's proposed new Trans Mountain pipeline. Conversations for Responsible Economic Development, Vancouver, British Columbia, Canada. [online] URL: http://credbc.ca/assessing-the-risks/

Chandrasekar, S., G. Sorial, and J. W. Weaver. 2006. Dispersant effectiveness on oil spills - impact of salinity. ICES Journal of Marine Science 63(8):1418-1430. http://dx.doi.org/10.1016/j. icesjims.2006.04.019

Chapman, H., K. Purnell, R. J. Law, and M. F. Kirby. 2007. The use of chemical dispersants to combat oil spills at sea: a review of practice and research needs in Europe. Marine Pollution Bulletin 54:827-838. http://dx.doi.org/10.1016/j.marpolbul.2007.03.012

Cheong, S.-M. 2011. A social assessment of the Hebei-Spirit oil spill. GeoJournal 76:539-549. http://dx.doi.org/10.1007/s10708-010-9368-4

Cheong, S.-M. 2012. Fishing and tourism impacts in the aftermath of the Hebei-Spirit oil spill. Journal of Coastal Research 28(6):1648-1653. http://dx.doi.org/10.2112/JCOASTRES-D-11-00079.1

Chia, F.-S. 1973. Killing of marine larvae by diesel oil. Marine Pollution Bulletin 4(2):29-30. http://dx.doi.org/10.1016/0025-326X (73)90208-7

Clark, T., B. Stong, and B. Benson. 1997. Recovery of tarmats using commercial shrimping boats during the Buffalo 292 spill. Pages 41-49 in International Oil Spill Conference Proceedings. IOSC, Washington, D.C., USA. [online] URL: http:// ioscproceedings.org/doi/pdf/10.7901/2169-3358-1997-1-41

Cohen, A., D. Nugegoda, and M. M. Gagnon. 2001. Metabolic responses of fish following exposure to two different oil spill remediation techniques. Ecotoxicology and Environmental Safety 48(3):306-310. http://dx.doi.org/10.1006/eesa.2000.2020

Conan, G., G. M. Dunnet, and D. J. Crisp. 1982. The long-term effects of the Amoco Cadiz oil spill [and discussion]. Philosophical Transactions of the Royal Society B: Biological Sciences 297 (1087):323-333. http://dx.doi.org/10.1098/rstb.1982.0045

Cross, W. E., C. M. Martin, and D. H. Thomson. 1987. Effects of experimental releases of oil and dispersed oil on Arctic nearshore macrobenthos. II. Epibenthos. Arctic 40:201-210. [online] URL: http://pubs.aina.ucalgary.ca/arctic/Arctic40-S-201. pdf

Danielson, E. J. 2011. A study of the economic impact of the Deepwater Horizon oil spill - Part 3: public perception. Greater New Orleans, Inc., New Orleans, Louisiana, USA. [online] URL: http://gnoinc.org/wp-content/uploads/Economic_Impact_Study_Part_III_Public Perception_FINAL.pdf
David Suzuki Foundation. 2013. Oil spill scenarios. Video. David Suzuki Foundation, Vancouver, British Columbia, Canada. [online] URL: http://www.davidsuzuki.org/flash/oil-spill.html

Davidson, C. I., R. F. Phalen, and P. A. Solomon. 2005. Airborne particulate matter and human health: a review. Aerosol Science and Technology 39(8):737-749. http://dx.doi.org/10.1080/02786820500191348

Dean, T. A., J. L. Bodkin, S. C. Jewett, D. H. Monson, and D. Jung. 2000. Changes in sea urchins and kelp following a reduction in sea otter density as a result of the Exxon Valdez oil spill. Marine Ecology Progress Series 199:281-291. http://dx.doi.org/10.3354/ meps199281

den Hartog, C., and R. P. W. M. Jacobs. 1980. Effects of the "Amoco Cadiz" oil spill on an eelgrass community at Roscoff (France) with special reference to the mobile benthic fauna. Helgoländer Meeresuntersuchungen 33:182-191. [online] URL: http://link. springer.com/article/10.1007/BF02414745\#page-1

Department of Fisheries and Oceans (DFO). 2011. Canadian Coast Guard environmental response: marine spills contingency plan - national chapter. Federal document. [online] URL: http:// www.ccg-gcc.gc.ca/CCG/ER/Marine-Spills-Contingency-Plan

De Vogelaere, A. P., and M. S. Foster. 1994. Damage and recovery in intertidal Fucus gardneri assemblages following the 'Exxon Valdez' oil spill. Marine Ecology Progress Series 106:263-271. http://dx.doi.org/10.3354/meps106263

EnviroEmerg Consulting. 2008. Major marine vessel casualty risk and response preparedness in British Columbia. Living Oceans Society, Sointula/Vancouver, British Columbia, Canada. [online] URL: http://www.livingoceans.org/sites/default/files/

LOS marine vessels report.pdf

Esclamado, L. 2011. Ensuring justice : claiming livelihood for communities in the U.S. Gulf Coast after the BP oil spill disaster. Michigan Journal of Social Work and Social Welfare II(I):24-38. [online] URL: http://mjsw.files.wordpress.com/2011/07/vol1-iss1sp11-esclamado.pdf

Etkin, D. S. 2004. Modeling oil spill response and damage costs. Freshwater spills symposium 2004. United States Environmental Protection Agency, Washington, D.C., USA. [online] URL: http:// www.epa.gov/swercepp/web/docs/oil/fss/fss04/etkin2 04.pdf

Fall, J. A., R. Miraglia, W. Simeone, C. J. Utermohle, and R. J. Wolfe. 2001. Long-term consequences of the Exxon Valdez oil spill for coastal communities of Southcentral Alaska (Technical Paper 264). Department of Fish and Game, Department of Subsistence, Juneau, Alaska, USA. [online] URL: http://www.arlis.org/docs/ vol1/A/47170529.pdf

Farm Futures Staff. 2013. Mississippi River reopens after oil spill. Farm Futures, February 4. [online] URL: http://farmfutures.com/ story-mississippi-river-reopens-after-oil-spill-0-94324

Fingas, M. F. 2012. The basics of oil spill cleanup. 3rd Edition. Taylor and Francis Group, Boca Raton, Florida, USA. http://dx.doi. org/10.1201/9781420032598

Finn, K. 2012. Two years after BP oil spill, tourists back in U.S. Gulf. Reuters, May 27. [online] URL: http://www.reuters.com/ article/2012/05/27/usa-bpspill-tourism-idUSL1E8GP15X20120527 
Foster, M. S., J. A. Tarpley, and S. L. Dearn. 1990. To clean or not to clean: the rationale, methods, and consequences of removing oil from temperate shores. Northwest Environmental Journal 6:105-120.

Fourcade, M. 2011. Cents and sensibility: economic valuation and the nature of Nature. American Journal of Sociology 116 (6):1721-77. http://dx.doi.org/10.1086/659640

Franklin, C. L., and L. J. Warner. 2011. Fighting chemicals with chemicals: the role and regulation of dispersants in oil spill response. Natural Resources and Environment 26(2):26-29. [online] URL: http://cdn.akingump.com/images/content/5/2/v4/5245/NREfall11-franklin-warner.pdf

García Negro, M. C., C. S. Villasante, and A. Carballo Penela. 2007. Compensating system for damages caused by oil spill pollution: background for the Prestige assessment damage in Galicia, Spain. Ocean and Coastal Management 50:57-66. http:// dx.doi.org/10.1016/j.ocecoaman.2006.08.014

García Negro, M. C., S. Villasante, A. Carballo Penela, and G. Rodríguez. 2009. Estimating the economic impact of the Prestige oil spill on the Death Coast (NW Spain) fisheries. Marine Policy 33(1):8-23. http://dx.doi.org/10.1016/j.marpol.2008.03.011

Garza, M. D., A. Prada, M. Varela, and M. X. Vázquez Rodríguez. 2009. Indirect assessment of economic damages from the Prestige oil spill: consequences for liability and risk prevention. Disasters 33(1):95-109. http://dx.doi.org/10.1111/ j.1467-7717.2008.01064.X

Garza-Gil, M. D., J. C. Surís-Regueiro, and M. M. VarelaLafuente. 2006. Assessment of economic damages from the Prestige oil spill. Marine Policy 30(5):544-551. http://dx.doi. org/10.1016/j.marpol.2005.07.003

George, M. 1961. Oil pollution of marine organisms. Nature 192:1209. http://dx.doi.org/10.1038/1921209a0

Goel, M. 2011. Air pollution from oil spill: a new threat to climate change. Journal of Coastal Environment 2:117-128.

Gohlke, J. M., D. Doke, M. Tipre, M. Leader, and T. Fitzgerald. 2011. A review of seafood safety after the Deepwater Horizon blowout. Environmental Health Perspectives 119:1062-1069. http://dx.doi.org/10.1289/ehp.1103507

Goldsmith, W. T., W. McKinney, M. Jackson, B. Law, T. Bledsoe, P. Siegel, J. Cumpston, and D. Frazer. 2011. A computercontrolled whole-body inhalation exposure system for the oil dispersant COREXIT EC9500A. Journal of Toxicology and Environmental Health, Part A 74:1368-1380. http://dx.doi. org/10.1080/15287394.2011.606793

Goodlad, J. 1996. Effects of the Braer oil spill on the Shetland seafood industry. Science of the Total Environment 186:127-133. http://dx.doi.org/10.1016/0048-9697(96)05091-7

Gosselin, P., S. E. Hrudey, M. A. Naeth, A. Plourde, R. Therrien, G. Van Der Kraak, and Z. Xu. 2010. Environmental and health impacts of Canada's oil sands industry. Royal Society of Canada Report. Royal Society of Canada, Ottawa, Ontario, Canada. [online] URL: http://rsc-src.ca/en/expert-panels/rsc-reports/ environmental-and-health-impacts-canadas-oil-sands-industry
Greater New Orleans, Inc. 2011. A study of the economic impact of the Deepwater Horizon oil spill - Part 2: moratoria. Greater New Orleans, Inc., New Orleans, Louisiana, USA. [online] URL: http://gnoinc.org/wp-content/uploads/Economic Impact_Study Part II Moratoria FINAL.pdf

Grigalunas, T. A., R. C. Anderson, G. M. Brown, Jr., R. Congar, N. F. Meade, and P. E. Sorensen. 1986. Estimating the cost of oil spills: lessons from the Amoco Cadiz incident. Marine Resource Economics 2(3):239-263.

Gunton, D. T., and S. Broadbent. 2012. A review of potential impacts to Coastal First Nations from an oil tanker spill associated with the Northern Gateway project. Coastal First Nations, Vancouver, British Columbia, Canada. [online] URL: http://coastalfirstnations.ca/publications-resources

Gutierrez, T. 2011. Identifying polycyclic aromatic hydrocarbondegrading bacteria in oil-contaminated surface waters at Deepwater Horizon by cultivation, stable isotope probing and pyrosequencing. Reviews in Environmental Science and Bio/ technology 10:301-305. http://dx.doi.org/10.1007/s11157-011-9252-9

Ha, M., W. J. Lee, S. Lee, and H.-K. Cheong. 2008. A literature review on health effects of exposure to oil spill. Journal of Preventive Medicine and Public Health 41(5):345-354. http://dx. doi.org/10.3961/jpmph.2008.41.5.345

Hall, C. J., W. J. Henry, III, and C. R. Hyder. 2011. Hopedale branch: a vessel of opportunity success story. International Oil Spill Conference Proceedings. 2011(1):1-14. http://dx.doi. org/10.7901/2169-3358-2011-1-407

Hamdan, L. J., and P. A. Fulmer. 2011. Effects of COREXIT® EC9500A on bacteria from a beach oiled by the Deepwater Horizon spill. Aquatic Microbial Ecology 63:101-109. http://dx. doi.org/10.3354/ame01482

Harley, C. D. G., K. M. Anderson, C. A.-M. Lebreton, A. MacKay, M. Ayala-Díaz, S. L. Chong, L. M. Pond, J. H. Amerongen Maddison, B. H. C. Hung, S. L. Iversen, and D. C. M. Wong. 2013. The introduction of Littorina littorea to British Columbia, Canada: potential impacts and the importance of biotic resistance by native predators. Marine Biology 160:1529-1541. http://dx.doi.org/10.1007/s00227-013-2206-8

Hazen, T. C., E. A. Dubinsky, T. Z. DeSantis, G. L. Andersen, Y. M. Piceno, N. Singh, J. K. Jansson, A. Probst, S. E. Borglin, J. L. Fortney, W. T. Stringfellow, M. Bill, M. E. Conrad, L. M. Tom, K. L. Chavarria, T. R. Alusi, R. Lamendella, D. C. Joyner, C. Spier, J. Bælum, M. Auer, M. L. Zemla, R. Chakraborty, E. L. Sonnenthal, P. D'haeseleer, H.-Y. N. Holman, S. Osman, Z. Lu, J. D. Van Nostrand, Y. Deng, J. Zhou, and O. U. Mason. 2010. Deep-sea oil plume enriches indigenous oil-degrading bacteria. Science 330(6001):204-208. http://dx.doi.org/10.1126/science.1195979

Herrington, P., G. Ball, and K. O’Halloran. 2006. Aquatic ecotoxicity of cutback bitumen. Land Transport New Zealand, Wellington, New Zealand. [online] URL: http://nzta.govt.nz/ resources/research/reports/285/docs/285.pdf

Hill, S., and J. Bryan. 1997. The economic impact of the Sea Empress spillage. International Oil Spill Conference Proceedings 1997(1):227-233. http://dx.doi.org/10.7901/2169-3358-1997-1-227 
Hodgins, D. O., J. H. Huang, D. S. Dunbar, and S. L. M. Hodgins. 1991. A high-resolution coupled hydrodynamic and oil spill modelling system applied to the port of Vancouver. Pages 39-56 in Proceedings of the Arctic and marine oil spill program ( AMOP) technical seminar, Vancouver, British Columbia. Environment Canada, AMOP, Ottawa, Ontario, Canada.

Höfer, T. 1998. Tainting of seafood and marine pollution. Water Research 32:3505-3512. http://dx.doi.org/10.1016/S0043-1354 (98)00173-0

Holmstrup, M., A. M. Bindesbl, G. J. Oostingh, A. Duschl, V. Scheil, H. R. Köhler, S. Loureiro, A. M. V. M. Soares, A. L. G. Ferreira, C. Kienle, A. Gerhardt, R. Laskowski, P. E. Kramarz, M. Bayley, C. Svendsen, and D. J. Spurgeon. 2010. Interactions between effects of environmental chemicals and natural stressors: a review. Science of the Total Environment 408:3746-3762. http:// dx.doi.org/10.1016/j.scitotenv.2009.10.067

Incardona, J. P., M. G. Carls, H. L. Day, C. A. Sloan, J. L. Bolton, T. K. Collier, and N. L. Scholz. 2009. Cardiac arrhythmia is the primary response of embryonic Pacific herring (Clupea pallasi) exposed to crude oil during weathering. Environmental Science and Technology 43:201-207. http://dx.doi.org/10.1021/es802270t

Innovative Emergency Management (IEM). 2010. A study of the economic impact of the Deepwater Horizon oil spill - Part 1: fisheries. Greater New Orleans, New Orleans, Louisiana, USA. [online] URL: http://gnoinc.org/wp-content/uploads/ Economic_Impact_Study_Part_____Full_Report.pdf

International Energy Agency (IEA). 2010. World Energy Outlook 2010. International Energy Agency, Paris, France.

International Oil Pollution Compensation Funds (IOPC). 2007. Technical guidelines to assist experts in the assessment of claims in the fisheries, mariculture and fish processing sectors, including subsistence and small-scale operations lacking evidence of earnings. International Oil Pollution Compensation Fund, London, UK. [online] URL: http://www.iopcfunds.org/uploads/tx iopcpublications/ Fisheries_Expert_Guidelines_e.pdf

International Tanker Owners Pollution Federation Limited (ITOPF). 2012. ITOPF oil tanker spill statistics 2012. International Tanker Owners Pollution Federation Limited, London, UK. [online] URL: http://www.itopf.com/news-andevents/documents/StatsPack.pdf

InterVISTAS. 2013. 2008 Port Metro Vancouver economic impact study: final report. InterVistas, Vancouver, British Columbia, Canada. [online] URL: http://portmetrovancouver. com/docs/default-source/about-facts-stats/2012-port-metro-vancouvereconomic-impact-study.pdf

Jacobs, R. P. W. M. 1980. Effects of the 'Amoco Cadiz' oil spill on the seagrass community at Roscoff with special reference to the benthic infauna. Marine Ecology Progress Series 2:207-212. http://dx.doi.org/10.3354/meps002207

Jacobsson, M. 2007. The international liability and compensation regime for oil pollution from ships - international solutions for a global problem Tulane Maritime Law Journal 32:1-34.

Jacques Whitford AXYS Ltd. 2008. Burrard Inlet environmental indicators report public consultation document. Burrard Inlet Environmental Action Program, Burnaby, British Columbia,
Canada. [online] URL: http://www.bieapfremp.org/pdf/ burrard_inlet_environmental_indicators_feb08.pdf

Jenssen, B. M. 1996. An overview of exposure to, and effects of, petroleum oil and organochlorine pollution in grey seals (Halichoerus grypus). Science of the Total Environment 186:109-118. http://dx.doi.org/10.1016/0048-9697(96)05089-9

Jewett, S. C., and T. A. Dean. 1997. The effects of the Exxon Valdez oil spill on eelgrass communities in Prince William Sound, Alaska, 1990-95. Alaska Department of Fish and Game Habitat and Restoration Division, Anchorage, Alaska. [online] URL: http://www.arlis.org/docs/vol1/41863126.pdf

Jewett, S. C., T. A. Dean, R. O. Smith, and A. Blanchard. 1999. 'Exxon Valdez' oil spill: impacts and recovery in the soft-bottom benthic community in and adjacent to eelgrass beds. Marine Ecology Progress Series 185:59-83. http://dx.doi.org/10.3354/ $\underline{\text { meps } 185059}$

Jones, R., C. Rigg, and L. Lee. 2010. Haida marine planning: First Nations as a partner in marine conservation. Ecology and Society

15(1): 12. [online] URL: http://www.ecologyandsociety.org/ vol15/iss1/art12/

Judson, R. S., M. T. Martin, D. M. Reif, K. A. Houck, T. B. Knudsen, D. M. Rotroff, M. Xia, S. Sakamuru, R. Huang, P. Shinn, C. P. Austin, R. J. Kavlock, and D. J. Dix. 2010. Analysis of eight oil spill dispersants using rapid, in vitro tests for endocrine and other biological activity. Environmental Science and Technology 44:5979-5985. http://dx.doi.org/10.1021/es102150z

Kazlauskiene, N., M. Z. Vosyliene, and E. Ratkelyte. 2008. The comparative study of the overall effect of crude oil on fish in early stages of development. Pages 307-316 in P. Hlavinek, O. Bonacci, J. Marsalek, and I. Mahrikova, editors. Dangerous pollutants (xenobiotics) in urban water cycle: proceedings of the NATO advanced research workshop on dangerous pollutants (xenobiotics) in urban water cycle, Lednice, Czech Republic, 3-6 May 2007. Springer Netherlands, Amsterdam, The Netherlands. http://dx. doi.org/10.1007/978-1-4020-6795-2_28

Kelly, E. N., D. W. Schindler, P. V. Hodson, J. W. Short, R. Radmanovich, and C. C. Nielsen. 2010. Oil sands development contributes elements toxic at low concentrations to the Athabasca River and its tributaries. Proceedings of the National Academy of Sciences 107:16178-16183. http://dx.doi.org/10.1073/pnas. 1008754107

Kiran, R. B. K. 2010. Liability and compensation for oil pollution damage - an examination Of IMO conventions. NUJS Law Review 3:399-422. [online] URL: http://www.nujslawreview.org/ pdf/articles/2010 4/bhanu.pdf

Kontovas, C. A., H. N. Psaraftis, and N. P. Ventikos. 2010. An empirical analysis of IOPCF oil spill cost data. Marine Pollution Bulletin 60:1455-1466. http://dx.doi.org/10.1016/j.marpolbul.2010.05.010

Kujawinski, E. B., M. C. Kido Soule, D. L. Valentine, A. K. Boysen, K. Longnecker, and M. C. Redmond. 2011. Fate of dispersants associated with the Deepwater Horizon oil spill. Environmental Science and Technology 45:1298-1306. http://dx. doi.org/10.1021/es103838p

Law, R. J., and J. Hellou. 1999. Contamination of fish and shellfish following oil spill incidents. Environmental Geosciences 6(2):90-98. 
Law, R. J., and C. Kelly. 2004. The impact of the "Sea Empress" oil spill. Aquatic Living Resources 17:389-394. http://dx.doi. org/10.1051/alr:2004029

Levings, C. D., and S. Samis. 2001. Site description and oceanography. Pages 15-19 in C. M. Stehr and T. Origuchi, editors. PICES scientific report No. 16 - environmental assessment of Vancouver Harbour data report for the PICES practical workshop. Sidney, British Columbia, Canada.

Li, H., and M. C. Boufadel. 2010. Long-term persistence of oil from the Exxon Valdez spill in two-layer beaches. Nature Geoscience 3:96-99. http://dx.doi.org/10.1038/ngeo749

Liu, X., and K. W. Wirtz. 2006. Total oil spill costs and compensations. Maritime Policy and Management 33(1):49-60. http://dx.doi.org/10.1080/03088830500513352

Liu, Y. Y., R. H. R. H. Weisberg, C. C. Hu, and L. L. Zheng. 2013. Trajectory forecast as a rapid response to the Deepwater Horizon oil spill. Pages 153-165 in Y. Y. Liu, A. Macfadyen, Z.-G. Ji, and R. H. Weisberg, editors. Monitoring and modeling the Deepwater Horizon oil spill: a record-breaking enterprise. American Geophysical Union, Washington, D. C., USA.

Lord, F., S. Tuler, T. Webler, and K. Dow.. 2012. Unnecessarily neglected in planning: illustration of a practical approach to identify human dimension impacts of marine oil spills. Journal of Environmental Assessment Policy and Management 14(2):1-23. http://dx.doi.org/10.1142/S1464333212500123

Loureiro, M. L., J. B. Loomis, and M. X. Vázquez. 2009. Economic valuation of environmental damages due to the Prestige Oil spill in Spain. Environmental and Resource Economics 44(4):537-553. http://dx.doi.org/10.1007/s10640-009-9300-x

Loureiro, M. L., A. Ribas, E. López, and E. Ojea. 2005. Estimated costs and admissible claims linked to the Prestige oil spill. Ecological Economics 59:48-63. http://dx.doi.org/10.1016/j. ecolecon.2005.10.001

Ma, J. Y. C., A. Rengasamy, D. Frazer, M. W. Barger, A. F. Hubbs, L. Battelli, S. Tomblyn, S. Stone, and V. Castranova. 2003. Inhalation exposure of rats to asphalt fumes generated at paving temperatures alters pulmonary xenobiotic metabolism pathways without lung injury. Environmental Health Perspectives 111:1215-1221. [online] URL: http://www.ncbi.nlm.nih.gov/pmc/ articles/PMC1241577/pdf/ehp0111-001215.pdf

Major, D. N., and H. Wang. 2012. How public health impact is addressed: a retrospective view on three different oil spills. Toxicological and Environmental Chemistry 94:442-467. http://dx. doi.org/10.1080/02772248.2012.654633

Martin, G. 1999. Valdez spill leaves bitter residue: oil is gone after 10 years, but ecological, economic fallout continues. San Francisco Chronicle, San Francisco, California, USA. [online] URL: http:// www.sfgate.com/news/article/Valdez-Spill-Leaves-Bitter-ResidueOil-is-gone-2940197.php

Mascarelli, A. 2010. Deepwater Horizon: after the oil. Nature 467:22-24. http://dx.doi.org/10.1038/467022a

Masliyah, J., Z. J. Zhou, Z. Xu, J. Czarnecki, and H. Hamza. 2004. Understanding water-based bitumen extraction from Athabasca oil sands. Canadian Journal of Chemical Engineering 82:628-654. http://dx.doi.org/10.1002/cjce.5450820403

Mason, M. 2002. Transnational compensation for oil pollution damage: examining changing spatialities of environmental liability. $L S E$ research papers in environmental and spatial analysis no. 69. Department of Geography and Environment, London School of Economics and Political Science, London, UK. [online] URL: http://eprints.1se.ac.uk/570/

Mason, M. 2003. Civil liability for oil pollution damage: examining the evolving scope for environmental compensation in the international regime. Marine Policy 27:1-12. http://dx.doi. org/10.1016/S0308-597X(02)00051-9

Matkin, C. O., E. L. Saulitis, G. M. Ellis, P. Olesiuk, and S. D. Rice. 2008. Ongoing population-level impacts on killer whales Orcinus orca following the 'Exxon Valdez' oil spill in Prince William Sound, Alaska. Marine Ecology Progress Series 356:269-281. http://dx.doi.org/10.3354/meps07273

McCammon, M. 2003. Evaluation of environmental damage by the Exxon Valdez incident. Issues concerning incidents on tanker routes. In Issues concerning incidents on tanker routes. Economics and technical perspectives. Economic evaluation of oil spill damage. Sponsored by Petroleum Association of Japan. Tokyo, Japan, February 27, 2003. Petroleum Association of Japan, Tokyo, Japan. [online] URL: http://www.pcs.gr.jp/doc/esymposium/2003/2003 McCammon E.pdf

McCoy, D. F., and N. Whittier. 2003. Modeling assessment of potential fates and exposure for orimulsion and heavy fuel oil spills. Proceedings of International Oil Spill Conference, 2003 (1):929-934. http://dx.doi.org/10.7901/2169-3358-2003-1-929

McDowell Group. 1990. An assessment of the impact of the Exxon Valdez oil spill on the Alaska tourism industry. McDowell Group, Juneau, Alaska, USA. [online] URL: http://www.evostc.state.ak. us/Universal/Documents/Publications/Economic/Econ_Tourism. pdf

McKenzie, L. A., R. C. Brooks, and E. L. Johnston. 2012. A widespread contaminant enhances invasion success of a marine invader. Journal of Applied Ecology 49(4):767-773. http://dx.doi. org/10.1111/j.1365-2664.2012.02158.x

McLinden, C. A., V. Fioletov, K. F. Boersma, N. Krotkov, C. E. Sioris, J. P. Veefkind, and K. Yang. 2012. Air quality over the Canadian oil sands: a first assessment using satellite observations. Geophysical Research Letters 39:L04804. http://dx.doi. org/10.1029/2011GL050273

Minder, R. 2012. Spanish court opens trial over giant Prestige oil spill. New York Times, October 16. [online] URL: http://www. nytimes.com/2012/10/17/world/europe/spanish-court-opens-trialover-giant-prestige-oil-spill.html? $\mathrm{r}=0$

Ministry of Justice (MOJ). 2013. Response organizations and oil handling facilities regulations. Canadian Ministry of Justice, Ottawa, Ontario, Canada. [online] URL: http://laws-lois.justice. gc.ca/PDF/SOR-95-405.pdf 
MMK Consulting. 2007. Economic impacts and prospects of the salmon farming and wild salmon industries in British Columbia. MMK Consulting, Vancouver, British Columbia, Canada.

Moldan, G. S., L. F. Jackson, S. McGibbon, and J. Van Der Westhuizen. 1985. Some aspects of the Castillo de Bellver oil spill. Marine Pollution Bulletin 16(3):97-102. http://dx.doi. org/10.1016/0025-326X(85)90530-2

Moller, T. H., B. Dicks, K. J. Whittle, and M. Girin. 1999. Fishing and harvesting bans in oil spill response. Proceedings of International Oil Spill Conference. 1999(1):693-699. [online] URL: http://www.itopf.com/assets/documents/fishban.pdf http:// dx.doi.org/10.7901/2169-3358-1999-1-693

Moncrieff, J., and C. H. Simpson. 1993. Economic and social impacts. Marine Policy 17(5):469-472. http://dx.doi.org/10.1016/0308-597X (93)90067-D

Moore, L. Y., A. J. Footitt, L. M. Reynolds, M. G. Postle, P. J. Flyod, T. Fenn, and S. Virani. 1998. Sea Empress cost-benefit project - final report research and development. Environment Agengy, Bristol, UK. [online] URL: http://www.rpaltd.co.uk/ documents/J200-SeaEmpress.pdf

Mos, L., J. Jack, D. Cullon, L. Montour, C. Alleyne, and P. S. Ross. 2004. The importance of marine foods to a near-urban First Nation community in coastal British Columbia, Canada: toward a risk benefit assessment. Journal of Toxicology and Environmental Health, Part A: Current Issues 67:791-808. http:// dx.doi.org/10.1080/15287390490428224a

Muskal, M. 2013. Cleanup continues after Mississippi River barge oil spill. Los Angeles Times, January 28. [online] URL: http://articles.latimes.com/2013/jan/28/nation/la-na-nn-cleanup-mississippiriver-barge-oil-spill-20130128

National Transportation Safety Board (NTSB). 2010. Pipeline accident report: Enbridge incorporated hazardous liquid pipeline rupture and release. National Transportation Safety Board, Washington, D.C., USA. [online] URL: https://www.ntsb.gov/ doclib/reports/2012/PAR1201.pdf

Nelson-Smith, A. 1971. The problem of oil pollution of the sea. Advances in Marine Biology 8:215-306. http://dx.doi.org/10.1016/ S0065-2881(08)60493-9

Nelson-Smith, A. 1973. Oil pollution and marine ecology. Plenum, New York, New York, USA.

North, W. J. 1973. Position paper on effects of acute oil spills. Background information for ocean affairs workshop on inputs, fates, and effects of petroleum in the marine environment, May 1973, Airlie, Virginia.

Nossiter, A. 2008. Mississippi River reopened after oil spill. New York Times, July 25. [online] URL: http://www.nytimes. com/2008/07/25/us/25spill.html

Nyman, T. 2009. Evaluation of methods to estimate the consequence costs of an oil spill. SKEMA Seventh Framework Programme, Athens, Greece.

Office of the Auditor General of Canada. 2010. Report of the commissioner of the environment and sustainable development to the House of Commons: chapter 1 - oil spills from ships. Government of Canada, Ottawa, Ontario, Canada. [online]
URL: http://www.oag-bvg.gc.ca/internet/English/ parl_cesd_201012_01_e_34424.html

Ormseth, O. A., and M. Ben-David. 2000. Ingestion of crude oil: effects on digesta retention times and nutrient uptake in captive river otters. Journal of Comparative Physiology B 170 (5-6):419-428. http://dx.doi.org/10.1007/s003600000119

Owens, E. H., W. Robson, and C. R. Foget. 1987. A field evaluation of selected beach-cleaning techniques. Arctic 40:244-257. [online] URL: http://pubs.aina.ucalgary.ca/arctic/ arctic40-s-244.pdf

Oxford Economics. 2010. Potential impact of the Gulf oil spill on tourism. Oxford Economics, London, UK. [online] URL: http://www.ustravel.org/sites/default/files/page/2009/11/ Gulf Oil Spill Analysis Oxford Economics 710.pdf

Pacific States/British Columbia Oil Spill Task Force. 2011. The stakeholder workgroup review of planning and response capabilities for a marine oil spill on the U.S./Canadian transboundary areas of the Pacific coast project report. Pacific States/British Columbia Oil Spill Task Force, Seattle, Washington, USA. [online] URL: http://oilspilltaskforce.org/docs/Final_US_Canada_Transboundary Project Report.pdf

Paine, R. T., J. L. Ruesink, A. Sun, E. L. Soulanille, M. J. Wonham, C. D. G. Harley, D. R. Brumbaugh, and D. L. Secord. 1996. Trouble on oiled waters: lessons from the Exxon Valdez oil spill. Annual Review of Ecology and Systematics 27:197-235. http://dx. doi.org/10.1146/annurev.ecolsys.27.1.197

Palinkas, L. A., M. A. Downs, J. S. Petterson, and J. Russell. 1993. Social, cultural, and psychological impacts of the Exxon Valdez oil spill. Human Organization 52:1-13.

Palmer, V. V. 2011. The great spill in the Gulf ... and a sea of pure economic loss: reflections on the boundaries of civil liability. Penn State Law Review 116:105-143. [online] URL: http://www. pennstatelawreview.org/print-issues/articles/the-great-spill-in-thegulf-and-a-sea-of-pure-economic-loss-reflections-on-the-boundariesof-civil-liability/

Pearson, W. H., S. M. Al-Ghais, J. M. Neff, C. J. Brandt, K. Wellman, and T. Green. 1998. Assessment of damages to commercial fisheries and marine environment of Fujairah, United Arab Emirates, resulting from the Seki oil spill of March 1994: a case study. Yale F\&ES Bulletin 103. [online] URL: http:// environment.research.yale.edu/documents/downloads/0-9/103pearson. pdf

Perry, R. 2011. The Deepwater Horizon oil spill and the limits of civil liability. Washington Law Review 86:1-68. [online] URL: https://digital.law.washington.edu/dspace-law/bitstream/ handle/1773.1/1005/86WLR1.pdf?sequence $=1$

Peterson, C. H., S. D. Rice, J. W. Short, D. Esler, J. L. Bodkin, B. E. Ballachey, and D. B. Irons. 2003. Long-term ecosystem response to the Exxon Valdez oil spill. Science 302 (5653):2082-2086.

Piatt, J. F., C. J. Lensink, W. Butler, M. Kendziorek, and D. R. Nysewander. 1990. Immediate impact of the 'Exxon Valdez' oil spill on marine birds. Auk 107:387-397. http://dx.doi. org/10.2307/4087623 
Pickrell, E. 2012. Exxon Valdez could affect BP settlement. Houston Chronicle. September 14.

Picou, J. S., B. K. Marshall, and D. A. Gill. 2004. Disaster, litigation, and the corrosive community. Social Forces 82:1493-1522. http://dx.doi.org/10.1353/sof.2004.0091

Piola, R. F., and E. L. Johnston. 2008. Pollution reduces native diversity and increases invader dominance in marine hardsubstrate communities. Diversity and Distributions 14:329-342. http://dx.doi.org/10.1111/j.1472-4642.2007.00430.x

Port Metro Vancouver. 2012. Transit procedures: Second Narrows. Port Metro Vancouver, Vancouver, British Columbia, Canada. [online] URL: http://www.portmetrovancouver.com/en/users/ marineoperations/navigation/TransitProcedures.aspx

Port Metro Vancouver. 2013. Tanker traffic: oil tanker movement. Port Metro Vancouver, Vancouver, British Columbia, Canada.

PR Newswire. 2013. Harper government announces first steps towards World-Class Tanker Safety System. PR Newswire, March 18. [online] URL: http://www.prnewswire.com/news-releases/ harper-government-announces-first-steps-towardsworld-class-tankersafety-system-198843381.html

Punzón, A., V. Trujillo, J. Castro, N. Perez, J. M. Bellido, E. Abad, B. Villamor, P. Abaunza, and F. Velasco. 2009. Closed area management taken after the 'Prestige' oil spill: effects on industrial fisheries. Marine Biodiversity Records 2(2009):e75. http://dx.doi.org/10.1017/S1755267209000517

Rhoan, E. 2011. The rightful position: the BP oil spill and the Gulf Coast tribes. San Joaquin Agricultural Law Review 20:173-192. [outline] URL: http://www.sjcl.edu/campus/images/ stories/sjalr/volumes/V20N1C7.pdf

Rice, S. D., R. E. Thomas, M. G. Carls, R. A. Heintz, A. C. Wertheimer, M. L. Murphy, J. W. Short, and A. Moles. 2001. Impacts to pink salmon following the Exxon Valdez oil spill: persistence, toxicity, sensitivity, and controversy. Reviews in Fisheries Science 9(3):165-211. http://dx.doi.org/10.1080/20016491101744

Ritchie, L. A., D. A. Gill, and J. S. Picou. 2011. The BP disaster as an Exxon Valdez rerun. Contexts 10(3):30-35. http://dx.doi. org/10.1177/1536504211418454

Ritchie, W. 1995. Maritime oil spills - environmental lessons and experiences with special reference to low-risk coastlines. Journal of Coastal Conservation 1:63-76. http://dx.doi.org/10.1007/ BF02835563

Rodin, M., M. Downs, J. Petterson, and J. Russell. 1992. Community impacts resulting from the Exxon Valdez oil spill. Organization and Environment 6(3):219-234. http://dx.doi. org/10.1177/108602669200600304

Rodríguez-Trigo, G., J. P. Zock, and I. Isidro Montes. 2007. Health effects of exposure to oil spills. Archivos de Bronconeumología 43 (11):628-635. http://dx.doi.org/10.1016/S1579-2129(07)60141-4

Rogers, V. V., M. Wickstrom, K. Liber, and M. D. MacKinnon. 2002. Acute and subchronic mammalian toxicity of naphthenic acids from oil sands tailings. Toxicological Sciences 66(2):347-355. http://dx.doi.org/10.1093/toxsci/66.2.347
Sabucedo, J. M., C. Arce, M. J. Ferraces, H. Merino, and M. Durán. 2009. Psychological impact of the Prestige catastrophe. International Journal of Clinical Health and Psychology 9:105-116. [online] URL: http://www.redalyc.org/pdf/337/33712020007.pdf

Sargian, P., S. Mas, É. Pelletier, and S. Demers. 2007. Multiple stressors on an Antarctic microplankton assemblage: water soluble crude oil and enhanced UVBR level at Ushuaia (Argentina). Polar Biology 30(7):829-841. http://dx.doi. org/10.1007/s00300-006-0243-1

Sayre, K. 2012. Mississippi River oil spill costs being battled in court four years later. New Orleans Times-Picayune, October 5. [online] URL: http://www.nola.com/environment/index.ssf/2012/10/ mississippi_river_oil_spill_co.html

Schoenbaum, T. J. 2012. Liability for damages in oil spill accidents: evaluating the USA and international law regimes in the light of Deepwater Horizon. Journal of Environmental Law 24(3):395-416. http://dx.doi.org/10.1093/jel/eqs006

Sheng, L., and D. O. Hodgins. 2004. A dynamically coupled outfall plume-circulation model for effluent dispersion in Burrard Inlet, British Columbia. Journal of Environmental Engineering and Science 3(5):433-449. http://dx.doi.org/10.1139/s04-039

Silliman, B. R., J. van de Koppel, M. W. McCoy, J. Diller, G. N. Kasozi, K. Earl, P. N. Adams, and A. R. Zimmerman. 2012. Degradation and resilience in Louisiana salt marshes after the BP-Deepwater Horizon oil spill. Proceedings of the National Academy of Sciences 109(28):11234-11239. http://dx.doi. org/10.1073/pnas.1204922109

Smith, Jr., L. C., M. Smith, and P. Ashcroft. 2010. Analysis of environmental and economic damages from British Petroleum's Deepwater Horizon oil spill. Albany Law Review 74(1):563-585. http://dx.doi.org/10.2139/ssrn.1653078

Sriram, K., G. X. Lin, A. M. Jefferson, W. T. Goldsmith, M. Jackson, W. McKinney, D. G. Frazer, V. A. Robinson, and V. Castranova. 2011. Neurotoxicity following acute inhalation exposure to the oil dispersant COREXIT EC9500A. Journal of Toxicology and Environmental Health A 74(21):1405-1418. http:// dx.doi.org/10.1080/15287394.2011.606796

Stone, J., M. Piscitelli, K. Demes, S. Chang, M. Quayle, and D. Withers. 2013. Economic and biophysical impacts of oil tanker spills relevant to Vancouver, Canada. Vancouver Economic Commission, Vancouver, British Columbia, Canada. http://www. vancouvereconomic.com/userfiles/file/Attachments/VEC $\% 20$ Report $\%$ 20- $\% 20$ Impacts $\% 20$ of $\% 20$ Oil $\% 20$ Tanker $\% 20$ Spills $\% 20$ Relevant $\%$ 20to $\% 20$ Vancouver.pdf

Stubblefield, W. A., R. H. McKee, R. W. Kapp, Jr., and J. P. Hinz. 1989. An evaluation of the acute toxic properties of liquids derived from oil sands. Journal of Applied Toxicology 9(1):59-65. http://dx.doi.org/10.1002/jat.2550090111

Sundbäck, K., C. Alsterberg, and F. Larson. 2010. Effects of multiple stressors on marine shallow-water sediments: response of microalgae and meiofauna to nutrient-toxicant exposure. Journal of Experimental Marine Biology and Ecology 388 (1-2):39-50. http://dx.doi.org/10.1016/j.jembe.2010.03.007 
Surís-Regueiro, J. C., M. D. Garza-Gil, and M. M. VarelaLafuente. 2007. The Prestige oil spill and its economic impact on the Galician fishing sector. Disasters 31(2):201-215. http://dx.doi. org/10.1111/j.1467-7717.2007.01004.X

Szaro, R. C. 1977. Effects of petroleum on birds. Transactions of the 42nd North American wildlife and natural resources conference 374-381. Wildlife Management Institute, Washington, D.C., USA. [online] URL: http://www.pwrc.usgs.gov/oilinla/pdfs/1991 Szaro. pdf

Thomson, R. E. 1981. Oceanography of the British Columbia coast. Canadian Special Publication of Fisheries and Aquatic Sciences 56. Fisheries and Oceans Canada, Ottawa, Ontario, Canada. [online] URL: http://www.dfo-mpo.gc.ca/librariesbibliotheques/toc-tdm/487-eng.htm

Transport Canada. 2010. Environmental prevention and response national preparedness plan. [online] URL: http://www.tc.gc.ca/ media/documents/marinesafety/tp13585-procedures-eprnpp-e.pdf

Trudel, B. K. 1998. Dispersant application in Alaska: a technical update. Proceedings of the conference: "dispersant use in Alaska: a technical update". Prince William Sound Oil Spill Recovery Institute, Cordova, Alaska, USA. [online] URL: http://www.pwsosri.org/publications/Dispersant_Application_Alaska_1998.pdf

Tucker, A., and M. O'Brien. 2011. Volunteers and oil spills - a technical perspective. International oil spill conference 2011, Portland, Oregon, USA. [online] URL: http://www.itopf.com/ information-services/publications/papers/documents/IOSC11.pdf

U.S. Department of Commerce. 1983. Assessing the social costs of oil spills: the Amoco Cadiz case study. U.S. Department of Commerce, Washington, D.C., USA. [online] URL: https:// ia600600.us.archive.org/15/items/assessingsocialc00unit/ assessingsocialc00unit.pdf

Upreti, S. R., A. Lohi, R. A. Kapadia, and R. El-Haj. 2007. Vapor extraction of heavy oil and bitumen: a review. Energy and Fuels 21(3):1562-1574. http://dx.doi.org/10.1021/ef060341j

van Tamelen, P. G., M. S. Stekoll, and L. Deysher. 1997. Recovery processes of the brown alga Fucus gardneri following the 'Exxon Valdez' oil spill: settlement and recruitment. Marine Ecology Progress Series 160:265-277. http://dx.doi.org/10.3354/meps160265

Vanderklippe, N. 2012. Trans mountain: the other Pacific pipeline. Globe and Mail. [online] URL: http://www. theglobeandmail.com/report-on-business/industry-news/energy-andresources/trans-mountain-the-other-pacific-pipeline/article4462228/? page $=$ all

Vosyliene, M. Z., N. Kazlauskiene, and K. Joksas. 2005. Toxic effects of crude oil combined with oil cleaner simple green on yolk-sac larvae and adult rainbow trout Oncorhynchus mykiss. Environmental Science and Pollution Research 12(3):136-139. http://dx.doi.org/10.1065/espr2005.04.245

Webler, T., and F. Lord. 2010. Planning for the human dimensions of oil spills and spill response. Environmental Management 45:723-738. http://dx.doi.org/10.1007/s00267-010-9447-9

Webster, L., M. Russell, G. Packer, and C. F. Moffat. 2006. Long term monitoring of polycyclic aromatic hydrocarbons (PAHs) in blue mussels (Mytilus edulis) from a remote Scottish location.
Polycyclic Aromatic Compounds 26:283-298. http://dx.doi. org/10.1080/10406630600904109

Wells, P. G. 1972. Influence of Venezuelan crude oil on lobster larvae. Marine Pollution Bulletin 3(7):105-106. http://dx.doi. org/10.1016/0025-326X(72)90250-0

Western Canada Marine Response Corporation (WCRMC). 2012. Information handbook. Western Canada Marine Response Corporation, Burnaby, British Columbia, Canada. [online] URL: http://wcmrc.com/wp-content/uploads/2013/06/WCMRC-InformationHandbook-2012.pdf

White, I. C., and J. M. Baker. 1998. The Sea Empress spill in context. International conference on the Sea Empress oil Spill, 11-13 February 1998. Cardiff, Wales, UK. [online] URL: http:// www.itopf.com/ assets/documents/seeec.pdf

White, I. C., and F. C. Molloy. 2003. Factors that determine the cost of oil spills. International oil spill conference 20032003 (1):1225-1229. [online] URL: http://www.itopf.com/ assets/ costs03.pdf http://dx.doi.org/10.7901/2169-3358-2003-1-1225

Whitehouse, B. G. 1984. The effects of temperature and salinity on the aqueous solubility of polynuclear aromatic hydrocarbons. Marine Chemistry 14(4):319-332. http://dx.doi.org/10.1016/0304-4203 (84)90028-8

Wirtz, K. W., N. Baumberger, S. Adam, and X. Liu. 2007. Oil spill impact minimization under uncertainty: evaluating contingency simulations of the Prestige accident. Ecological Economics 61 (2-3):417-428. http://dx.doi.org/10.1016/j.ecolecon.2006.03.013

Wolfe, M. F., H. E. Olsen, K. A. Gasuad, R. S. Tjeerdema, and M. L. Sowby. 1999. Induction of heat shock protein (hsp)60 in Isochrysis galbana exposed to sublethal preparations of dispersant and Prudhoe Bay crude oil. Marine Environmental Research 47:473-489. http://dx.doi.org/10.1016/S0141-1136(98) $\underline{00132-9}$

Zock, J.-P., G. Rodríguez-Trigo, F. Pozo-Rodríguez, J. A. Barberá, L. Bouso, Y. Torralba, J. M. Antó, F. P. Gomez, C. Fuster, and H. Verea. 2007. Prolonged respiratory symptoms in clean-up workers of the Prestige oil spill. American Journal of Respiratory and Critical Care Medicine 176(6):610-616. 


\section{Appendix 1. Key Variables in Oil Spill Impact Framework}

\section{Table A1.1 Oil spill variables}

\begin{tabular}{lll}
\hline \hline Variable & Effect & Citations \\
\hline Ship safety features & $\begin{array}{l}\text { Double-hulled ships are less accident-prone than } \\
\text { single-hulled ships and spills from double-hulled } \\
\text { ships may be less costly. }\end{array}$ & $\begin{array}{l}\text { Burgherr 2007; Nyman 2009; Alló } \\
\text { and Loureiro 2013 }\end{array}$ \\
Location of spill & $\begin{array}{l}\text { Offshore spills have less direct economic impacts } \\
\text { than nearshore spills in proximity of human } \\
\text { populations. }\end{array}$ & $\begin{array}{l}\text { White and Molloy 2003; Kontavos } \\
\text { et al. 2010 }\end{array}$ \\
Spill amount and rate & $\begin{array}{l}\text { Increased amount of oil spilled increases total } \\
\text { damages. Continued release of oil over months } \\
\text { necessitates multiple waves of response efforts. }\end{array}$ & $\begin{array}{l}\text { White and Molloy 2003; Loureiro } \\
\text { et al. 2005; Punzon et al. 2009; } \\
\text { Type of and Loureiro 2013 }\end{array}$ \\
& $\begin{array}{l}\text { Chemical composition of oil influences dispersal } \\
\text { characteristics (distance, depth, and degradation } \\
\text { rate) and toxicity. }\end{array}$ & $\begin{array}{l}\text { McCoy and Whittier 2003; } \\
\text { Herrington et al. 2006 }\end{array}$ \\
\hline
\end{tabular}


Table A1.2 Disaster management variables

\begin{tabular}{|c|c|c|}
\hline Variable & Effect & Citations \\
\hline $\begin{array}{l}\text { Timing of } \\
\text { response }\end{array}$ & $\begin{array}{l}\text { A rapid response can reduce oil spill impacts by } \\
\text { orders of magnitude. }\end{array}$ & $\begin{array}{l}\text { U.S. Department of Commerce } \\
\text { 1983; Grigalunas et al. 1986; } \\
\text { White and Baker 1998; White and } \\
\text { Molloy 2003; Nyman 2009 }\end{array}$ \\
\hline Governance & $\begin{array}{l}\text { Response plans and on-scene command structures } \\
\text { play a critical role in reducing impacts. }\end{array}$ & $\begin{array}{l}\text { U.S. Department of Commerce } \\
\text { 1983; Rodin et al. 1992; Ritchie } \\
\text { 1995; White and Molloy } 2003\end{array}$ \\
\hline $\begin{array}{l}\text { Response } \\
\text { technology }\end{array}$ & $\begin{array}{l}\text { The mix of technologies used to respond (e.g., } \\
\text { dispersants, skimmers, manual collection) can } \\
\text { increase or decrease response efficiency. These } \\
\text { technologies may also create their own short- and } \\
\text { long-term damages. Improvements in technology are } \\
\text { also driving up response costs. }\end{array}$ & $\begin{array}{l}\text { George 1961; Foster et al. 1990; } \\
\text { De Vogelaere and Foster 1994; } \\
\text { Ritchie 1995; Moore et al. 1998; } \\
\text { Pearson et al. 1998; Trudel 1998; } \\
\text { White and Baker 1998; Cohen et } \\
\text { al. 2001; White and Molloy 2003; } \\
\text { Vosyliene et al. 2005; Franklin and } \\
\text { Warner 2011; Cheong 2012; } \\
\text { Fingas 2012 }\end{array}$ \\
\hline Human capital & $\begin{array}{l}\text { The use of volunteers, military, and other non-market } \\
\text { labor can affect response costs (both positively and } \\
\text { negatively). }\end{array}$ & $\begin{array}{l}\text { Loureiro et al. 2005; Cheong 2011; } \\
\text { Fourcade 2011; Tucker and } \\
\text { O'brien } 2011\end{array}$ \\
\hline Natural processes & $\begin{array}{l}\text { Oil-eating bacteria and other natural processes affect } \\
\text { recovery times. Some natural process can be reduced } \\
\text { by human cleanup strategies (e.g., dispersants can } \\
\text { affect oil-eating bacteria). }\end{array}$ & $\begin{array}{l}\text { Hazen et al. 2010; Gutierrez 2011; } \\
\text { Hamdan and Fulmer } 2011 .\end{array}$ \\
\hline $\begin{array}{l}\text { Local culture and } \\
\text { context }\end{array}$ & $\begin{array}{l}\text { The scale of cleanup demanded by citizens is } \\
\text { culturally specific (i.e., different countries require } \\
\text { different levels of recovery) and has increased over } \\
\text { time. Also, costs vary by local economic context. } \\
\text { Response and recovery are more expensive in some } \\
\text { countries than others. }\end{array}$ & $\begin{array}{l}\text { Wirtz et al., 2007; Nyman, 2009; } \\
\text { Kontovas et al., 2010; Alló and } \\
\text { Loureiro, 2013; Fingas, } 2013\end{array}$ \\
\hline
\end{tabular}


Table A1.3 Marine physical environment variables

\begin{tabular}{|c|c|c|}
\hline Variable & Effect & Citations \\
\hline Connecting waterways & $\begin{array}{l}\text { Interconnectivity of waterways allows oil to } \\
\text { leave the waterway where the spill occurred and } \\
\text { enter other waterways, impacting other } \\
\text { municipalities }\end{array}$ & \\
\hline Tides and currents & $\begin{array}{l}\text { Ambient tide and current conditions will dictate } \\
\text { the dispersal rate and direction of the spilled oil }\end{array}$ & $\begin{array}{l}\text { e.g., Hodgins et al. 1991; Sheng } \\
\text { and Hodgins 2004; David Suzuki } \\
\text { Foundation } 2013\end{array}$ \\
\hline Wave exposure & $\begin{array}{l}\text { Sites exposed to waves will exhibit increased } \\
\text { rates of natural degradation of oil over sheltered } \\
\text { waterways }\end{array}$ & $\begin{array}{l}\text { Owens et al. 1987; Carls et al. } \\
2001\end{array}$ \\
\hline $\begin{array}{l}\text { Temperature and } \\
\text { salinity }\end{array}$ & $\begin{array}{l}\text { Temperature and salinity influence solubility of } \\
\text { oil, rates of oil degradation and effectiveness of } \\
\text { oil dispersants }\end{array}$ & $\begin{array}{l}\text { Whitehouse 1984; Blondina et al. } \\
\text { 1999; Chandrasekar et al. } 2006\end{array}$ \\
\hline $\begin{array}{l}\text { Substrate at site } \\
\text { exposed to oil }\end{array}$ & $\begin{array}{l}\text { Contrary to sites with rocky substrate, oil can } \\
\text { penetrate deeply into sandy sediments and can } \\
\text { persist for decades }\end{array}$ & $\begin{array}{l}\text { Carls et al. 2001; Li and Boufadel } \\
2010\end{array}$ \\
\hline Weather conditions & $\begin{array}{l}\text { Prevalent winds may change the dispersal } \\
\text { patterns of surface oil (favourably or } \\
\text { unfavourably) and may inhibit response efforts }\end{array}$ & $\begin{array}{l}\text { Moldan et al. 1985; Law and Kelly } \\
\text { 2004; Wirtz et al. } 2007\end{array}$ \\
\hline
\end{tabular}


Table A1.4 Marine biology variables

\begin{tabular}{|c|c|c|}
\hline Variable & Effect & Citations \\
\hline Exposure to toxins & $\begin{array}{l}\text { Heavy crude oil products are often diluted with } \\
\text { toxic chemicals, posing an additional hazard }\end{array}$ & $\begin{array}{l}\text { e.g., Stubblefield et al. 1989; } \\
\text { Upreti et al. } 2007\end{array}$ \\
\hline Exposure quantity & $\begin{array}{l}\text { Increased oil exposure increases initial injury as } \\
\text { well as recovery time (usually non-linearly) }\end{array}$ & Silliman et al. 2012 \\
\hline Habitat/ depth of species & $\begin{array}{l}\text { Subsurface species will have reduced exposure } \\
\text { to oil (assuming that the majority of the oil } \\
\text { does not sink), while species near the surface } \\
\text { and in intertidal zones will have the highest } \\
\text { exposure to oil }\end{array}$ & \\
\hline Mobility & $\begin{array}{l}\text { Highly mobile species may be able to move } \\
\text { away from spill areas, reducing their exposure, } \\
\text { while sedentary species are not }\end{array}$ & \\
\hline Feeding mode & $\begin{array}{l}\text { Filter-feeding species tend to accumulate oil } \\
\text { while feeding and are particularly vulnerable }\end{array}$ & Law and Hellou 1999 \\
\hline Species identity & $\begin{array}{l}\text { Even closely related species at the same site } \\
\text { can differ in their susceptibility to and recovery } \\
\text { from an oiling event }\end{array}$ & e.g., North 1973 \\
\hline Other stressors & $\begin{array}{l}\text { Toxic effects of oil can be additive or } \\
\text { synergistic with other environmental stressors }\end{array}$ & $\begin{array}{l}\text { Peterson et al. 2003; Sargian et al. } \\
\text { 2007; Holmstrup et al. 2010; } \\
\text { Sundbäck et al. } 2010\end{array}$ \\
\hline Developmental stage & $\begin{array}{l}\text { Larvae and early developmental stages are } \\
\text { particularly vulnerable to oil toxicity }\end{array}$ & $\begin{array}{l}\text { Wells 1972; Chia 1973; Rice et al } \\
\text { 2001; Kazlauskiene et al. } 2008\end{array}$ \\
\hline Generation time & $\begin{array}{l}\text { Generally, species with slower generation times } \\
\text { take longer to recover from a spill event }\end{array}$ & Conan et al. 1982 \\
\hline
\end{tabular}


Table A1.5 Human health and society variables

\begin{tabular}{|c|c|c|}
\hline Variable & Effect & Citations \\
\hline $\begin{array}{l}\text { Direct skin contact with } \\
\text { carcinogenic compounds }\end{array}$ & $\begin{array}{l}\text { The composition of crude oil contains Volatile } \\
\text { Organic Compounds (VOCs), which are } \\
\text { carcinogenic and may affect the nervous } \\
\text { system. They may also have a range of lesser } \\
\text { effects and irritations. }\end{array}$ & $\begin{array}{l}\text { Jenssen 1996; Ormseth and Ben- } \\
\text { David 2000; Baars 2002; } \\
\text { Herrington et al. 2006; Rodríguez- } \\
\text { Trigo et al. 2007; Ha et al. 2008; } \\
\text { Major and Wang } 2012 .\end{array}$ \\
\hline Air pollutants & $\begin{array}{l}\text { Air pollutants from oil spills can affect human } \\
\text { health and exacerbate pre-existing conditions. }\end{array}$ & $\begin{array}{l}\text { Davidson et al. 2005; Jacques } \\
\text { Whitford AXYS Ltd. } 2008\end{array}$ \\
\hline $\begin{array}{l}\text { Ingestion of } \\
\text { contaminated food and } \\
\text { water }\end{array}$ & $\begin{array}{l}\text { Adverse health impacts via ingestion are also } \\
\text { possible by eating potentially contaminated } \\
\text { seafood, drinking contaminated water, or other } \\
\text { forms of ingestion }\end{array}$ & $\begin{array}{l}\text { Szaro 1977; Piatt et al. 1990; Hofer } \\
\text { 1998; Law and Hellou 1999; } \\
\text { Ormseth and Ben-David 2000; } \\
\text { Webster et al. 2006; Matkin et al. } \\
\text { 2008; Aguilera et al. 2010; Gohlke } \\
\text { et al. 2011; Barron } 2012\end{array}$ \\
\hline $\begin{array}{l}\text { Psychological and social } \\
\text { costs }\end{array}$ & $\begin{array}{l}\text { Work stoppages, shorter life expectancy, and } \\
\text { other effects impact the economy. Moreover, } \\
\text { increases in stress, drug and alcohol abuse, } \\
\text { crime, etc., create further social costs. }\end{array}$ & $\begin{array}{l}\text { Rodin et al. 1992; Palinkas et al. } \\
\text { 1993; Moore et al. 1998; Picou et } \\
\text { al. 2004; Loureiro et al. } 2005\end{array}$ \\
\hline Subsistence uses & $\begin{array}{l}\text { Impacts on subsistence economies, social and } \\
\text { cultural uses of natural resources, and social } \\
\text { structures are routine. This may also impact } \\
\text { other ethnic and social enclaves. }\end{array}$ & $\begin{array}{l}\text { Rodin et al. 1992; Palinkas et al. } \\
\text { 1993; Martin 1999; Fall et al. } \\
\text { 2001; Esclamado 2011; Rhoan } \\
\text { 2011 }\end{array}$ \\
\hline
\end{tabular}


Table A1.6 Economic variables

\begin{tabular}{|c|c|c|}
\hline Variable & Effect & Citations \\
\hline $\begin{array}{l}\text { Commercial fisheries } \\
\text { and aquaculture }\end{array}$ & $\begin{array}{l}\text { Fisheries businesses suffer direct losses from } \\
\text { product mortality, harvesting closures, loss of } \\
\text { market demand, brand damage, etc. }\end{array}$ & $\begin{array}{l}\text { Moldan et al. 1985; Grigalunas et } \\
\text { al. 1986; Moncrieff and Simpson } \\
\text { 1993; Goodlad 1996; Pearson et al. } \\
\text { 1998; Martin 1999; Moller et al. } \\
\text { 1999; Law and Kelly 2004; } \\
\text { Loureiro et al. 2005; Garza-Gil et } \\
\text { al. 2006; Surís-Regueiro et al. } \\
\text { 2007; Punzon et al. 2009; Cheong } \\
\text { 2012 }\end{array}$ \\
\hline $\begin{array}{l}\text { Commercial fisheries } \\
\text { and aquaculture value } \\
\text { chain }\end{array}$ & $\begin{array}{l}\text { Due to direct losses, businesses that depend on } \\
\text { commercial fisheries such as docks, processors, } \\
\text { distributors, and supply companies lose product } \\
\text { inputs and markets. }\end{array}$ & $\begin{array}{l}\text { U.S. Department of Commerce } \\
\text { 1983; Moncrieff and Simpson } \\
\text { 1993; Garcia Negro et al. } 2009\end{array}$ \\
\hline Tourism industry & $\begin{array}{l}\text { Brand damage from an oil spill can impact } \\
\text { businesses providing accomodations, } \\
\text { transportation, guides, activites (e.g. } \\
\text { recreational fishing), tourism-related retail, etc. } \\
\text { These market impacts can spread beyond the } \\
\text { direct oil spill zone. }\end{array}$ & $\begin{array}{l}\text { U.S. Department of Commerce } \\
\text { 1983; McDowell Group 1990; } \\
\text { Butler and Fennell 1994; Hill and } \\
\text { Bryan 1997; Moore et al. 1998; } \\
\text { Martin 1999; McCammon 2003; } \\
\text { Loureiro et al. 2005; Garza et al. } \\
\text { 2009; Oxford Economics 2010; } \\
\text { Danielson } 2011\end{array}$ \\
\hline
\end{tabular}

Waterway usage

Other marine-based industries

Oil industry

Agriculture

Pure economic loss
An oil spill may impede or shut down waterway uses, so the greater the use of a waterway, the larger the effect of its closure

Industries that pump water for cooling and other processes are vulnerable to oil spills. Transportation industries such as ferries and float planes may also be affected.

The oil industry itself may lose access to products or markets through affected waterways, and may be subject to regulatory moratoria on operations.

Marine-based agriculture (e.g., seaweed farms) can be affected, and farms adjacent to waterways may be affected by airborne mists or damage from cleanup operations.

Losses that occur independently of direct damage. These damages may ripple across the economy, spreading to goods and services providers that rely on spending from affected populations.
U.S. Department of Commerce 1983; Moore et al. 1998

Moncrieff and Simpson 1993; Moore et al. 1998; Greater New Orleans Inc. 2011

U.S. Department of Commerce 1983; Moller et al. 1999

Grigalunas et al. 1986; Palmer 2011; Perry 2011 
Passive use and recreation

Real estate

Financial sector

Legal and research costs

Municipal/regional government impacts

Economies of scale

Recovery boom

Expense savings

Tax revenues

Conservation benefits
Non-market losses to natural environments and recreational opportunities are usually significant results of an oil spill.

"Pure stigma" losses that devalue coastal or regional properties due to adjacency to the spill.

Lending and credit markets can be affected by defaults from impacted businesses.

Shareholders may lose value from falling share prices. The economy may experience inflation.

Oil spills require interventions by the legal profession to negotiate claims, and extensive research to establish baselines and measure impacts.

Direct administrative costs, increased demand for public services, and loss of tax revenues can strain government budgets. Opportunity costs, loss of staff to cleanup efforts, municipal/ regional brand damage, and political fallout are also factors impacting governments.

Once initial costs are invested into a cleanup, marginal costs of additional oil decrease per gallon.

Short-term economic losses are offset by increases in spending related to the response and recovery. Tourism businesses, retail, contractors, and local labor can all benefit.
Assaf et al. 1986; Carson et al. 2003; McCammon 2003; Peterson et al. 2003; Garza et al. 2009; Loureiro et al. 2009; Fourcade 2011

Grigalunas et al. 1986; Oxford Economics 2010; Smith et al. 2010; Cheong 2012; Pickrell 2012

U.S. Department of Commerce 1983; Moncrieff and Simpson 1993; Palinkas et al. 1993; Smith et al. 2010

U.S. Department of Commerce 1983; Law and Kelly 2004; Loureiro et al. 2005; Liu and Wirtz 2006; Fourcade 2011; Minder 2012

Rodin et al. 1992; Palinkas et al. 1993; Moncrieff and Simpson 1993; Hill and Bryan 1997; Moore et al. 1998; Picou et al. 2004;

Cheong 2011

Etkin 2004; Brody et al. 2012

U.S. Department of Commerce 1983; McDowell Group 1990; Butler and Fennell 1994; Clark et al. 1997; Hill and Bryan 1997; Moore et al. 1998; Loureiro et al. 2005; IEM 2010; Cheong 2011; Danielson 2011; Hall et al. 2011; Palinkas et al. 2011; Rodin et al. 2011

U.S. Department of Commerce 1983; Loureiro et al. 2005; GarzaGil et al. 2006 commercial fishers spend less on diesel, bait, etc.).

Due to increased recovery spending, governments may experience short-term tax revenue increases on sales of goods and services.

U.S. Department of Commerce 1983; Barker 2011

Hill and Bryan 1997; Moller et al. 1999; Loureiro et al. 2005; Punzon et al. 2009 
Table A1.7 Policy and decision variables

\begin{tabular}{lll}
\hline \hline Variable & Effect & Citations \\
\hline Port closure & $\begin{array}{l}\text { Marine transport losses are usually only a } \\
\text { fraction of oil spill losses, though some } \\
\text { examples of port closures due to river-based } \\
\text { spills have been noted. }\end{array}$ & $\begin{array}{l}\text { Wirtz, et al. 2007; Nossiter 2008; } \\
\text { Sayre 2012; Farm Futures 2013; } \\
\text { Muskal 2013 }\end{array}$ \\
& $\begin{array}{l}\text { In addition to losses, further investments may } \\
\text { be required to revive local brands in the } \\
\text { fisheries, tourism, and municipal sectors. }\end{array}$ & $\begin{array}{l}\text { Grigalunas et al. 1986; Moncrieff } \\
\text { and Simpson 1993; Goodlad 1996; } \\
\text { Moore et al. 1998; Loureiro et al. }\end{array}$ \\
& $\begin{array}{l}\text { 2005; Cheong 2012; Finn 2012 } \\
\text { Cransfers from compensatory regimes and other } \\
\text { sources can offset individual losses and soften } \\
\text { the economic impact of oil spills. }\end{array}$ & $\begin{array}{l}\text { Butler and Fennell 1994; Punzon et } \\
\text { al. 2009; Barker 2011; Ritchie et } \\
\text { al. 2011 }\end{array}$ \\
& $\begin{array}{l}\text { Fisheries bans cause direct losses to fisheries } \\
\text { businesses, but such losses are admissible under } \\
\text { Fishing moratoria }\end{array}$ & IOPC 2007 \\
& compensation regimes. & \\
\hline
\end{tabular}

